\title{
Antarctic climate change and the environment: an update
} John Turner*, Nicholas E. Barrand, Thomas J. Bracegirdle, Peter Convey*, Dominic A. Hodgson*, Martin Jarvis, Adrian Jenkins, Gareth Marshall, Michael P. Meredith, Howard Roscoe and Jon Shanklin

British Antarctic Survey, High Cross, Madingley Road, Cambridge, CB3 0ET (jtu@ bas.ac.uk)

John French

Australian Antarctic Division, 203 Channel Highway, Kingston TAS 7050, Australia

\section{Hugues Goosse}

Université Catholique de Louvain, Place de l’Université 1, 1348 Louvain-La-Neuve, Belgium

\section{Mauro Guglielmin}

The University of Insubria, Via Ravasi, 2 - 21100 Varese, Italy

\section{Julian Gutt*}

Alfred Wegener Institute Helmholtz Centre for Polar and Marine Research, P.O. Box 1201 61, 27515 Bremerhaven, Germany

\section{Stan Jacobs}

Columbia University, 2960 Broadway, New York, NY 10027, USA

\section{Marlon C. Kennicutt II}

Texas A\&M University, College Station, TX 77843-1342, USA

\section{Valerie Masson-Delmotte}

LSCE, Bat 701, L'Orme des Merisiers, CEA Saclay 91191 Gif-sur-Yvette cédex, France

\section{Paul Mayewski*}

Climate Change Institute, University of Maine, Orono, Maine, USA

\section{Francisco Navarro}

Technical University of Madrid, Av Ramiro de Maeztu, 7, 28040 Madrid, Spain

\section{Sharon Robinson}

Institute for Conservation Biology and Environmental Management, Department of Biological Sciences, University of Wollongong, NSW 2522, Australia

\section{Ted Scambos}

US National Snow and Ice Data Center, 1540 30th Street Boulder, CO 80303, USA

\section{Mike Sparrow* and Colin Summerhayes}

Scott Polar Research Institute, University of Cambridge, Lensfield Road, Cambridge, CB2 1ER

\section{Kevin Speer}

Florida State University, 790 E Broward Blvd, Fort Lauderdale, FL 33301, USA

\section{Alexander Klepikov*}

Arctic and Antarctic Research Institute, 38 Bering Street, Saint Petersburg, 199397 Russia

Received December 2012; first published online 18 April 2013

ABSTRACT. We present an update of the 'key points' from the Antarctic Climate Change and the Environment (ACCE) report that was published by the Scientific Committee on Antarctic Research (SCAR) in 2009. We summarise subsequent advances in knowledge concerning how the climates of the Antarctic and Southern Ocean have changed in the past, how they might change in the future, and examine the associated impacts on the marine and terrestrial biota. We also incorporate relevant material presented by SCAR to the Antarctic Treaty Consultative Meetings, and make use of emerging results that will form part of the Intergovernmental Panel on Climate Change (IPCC) Fifth Assessment Report.

\footnotetext{
* These authors are members of the SCAR ACCE Advisory Group
} 


\section{Introduction}

Between 2006 and 2008 the Scientific Committee on Antarctic Research (SCAR) undertook a major review of the state and current understanding of Antarctic and Southern Ocean climate science. The study spanned change from Deep Time, through the Holocene and the instrumental period, to predictions of possible change over the next century under a range of greenhouse gas emission scenarios. The project Antarctic Climate Change and the Environment (ACCE), was first discussed by the SCAR executive committee at its meeting in Bremen in July 2004, at which it was agreed that SCAR should consider carrying out an Antarctic climate assessment as a counterpart to the Arctic Climate Impact Assessment to contribute to the Antarctic Treaty Consultative Meeting (ATCM) and the Intergovernmental Panel on Climate Change (IPCC) deliberations. The plan for the assessment was approved by the executive committee at its meeting in Sofia, Bulgaria in July 2005 and formally approved by SCAR delegates in Hobart, Australia in July 2006. The form and scope of the project was defined at a SCAR cross-Standing Scientific Group meeting in November 2006 with the writing and editing taking place over the following two years. The project was coordinated by a nine-person steering committee with a total of 97 scientists from 12 countries eventually contributing to the writing. A draft of the report was distributed and made accessible for comment to the international Antarctic science community and beyond, leading to further revision during 2008 and 2009. The resulting 526page report (Turner and others 2009a) was launched at the Science Media Centre in the Royal Institution, London on 30 November 2009. At the same time, a summary review of the report was published in the scientific journal Antarctic Science (Convey and others 2009).

Hardcopy versions of the report were distributed to all the contributors, the 53 national representatives at the UN Framework Convention on Climate Change meeting in Copenhagen, five UN agencies, all 35 SCAR national delegates and several polar libraries. An online PDF version of the report is available to download without cost from the SCAR web site (http://www.scar.org/publications/occasionals/acce.html) or hardcopies are available to purchase from http://www.scar.org/publications/.

During the preparation of the ACCE report it became apparent that many areas of Antarctic science were advancing at a rapid pace and the editors strove to add the latest results up until the time of printing of the volume. However, it was also clear that while a large part of the ACCE report would have lasting value as background material, it would be necessary to update the report on a regular basis as new research results emerged. Short information papers describing recent advances in Antarctic climate change and its possible impacts on biota were presented to the ATCM in May 2010 (Punta del Este, Uruguay), June 2011 (Buenos Aires, Argentina) and June 2012 (Hobart, Australia). These are at http://www.scar. org/publications/occasionals/acce.html. While these updates provided selected research highlights, a more indepth update on climate-related advances was still required. Here we update the 'key points' from the 2009 ACCE report. Whereas the original key points were an executive summary of the full ACCE report and therefore did not incorporate citations, the present paper is intended as a stand alone report and includes a selection of key, mostly recent, references. The 2009 ACCE report should be consulted for comprehensive reference to the previous literature.

Many of the key points from the original ACCE report are still valid and have been left largely unchanged if the science has not advanced significantly. Some areas of science have developed rapidly since 2009 and the entries have been rewritten completely to reflect the progress.

\section{The Antarctic climate system}

1. The Antarctic climate system varies on timescales from orbital (tens to hundreds of thousands of years), to millennial to sub-annual and is closely coupled to other parts of the global climate system. The ACCE report discussed these variations from the perspective of the geological record and the recent historical period of instrumental data (approximately the last 50 years), discussed the consequences for the biosphere, and documented the latest numerical model projections of changes into the future, taking into account human influence through the release of greenhouse gases and chlorofluorocarbons to the atmosphere. The report highlighted the large uncertainties in the vulnerability of the West Antarctic Ice Sheet (WAIS). The profound impact of the ozone hole on the Antarctic environment over the last 30 years, shielding the continent from much of the effect of global warming was noted. This effect is not expected to persist. Over the next century ozone concentrations above the Antarctic are expected to recover and, if greenhouse gas atmospheric concentrations continue to increase at the present rate, temperatures across the continent are projected to increase by several degrees and sea ice will be reduced by about one third.

\section{The geological dimension (Deep Time)}

2. Studying the history of climate and the environment provides a context for understanding present day climate and environmental changes. It allows researchers to determine the processes that led to the development of the present interglacial period and to define the ranges of natural climate and environmental variability on timescales from decades to millennia over the past million years, and at coarser resolution across deep geological timescales. Knowing this natural variability, researchers can identify when present day changes exceed the natural range. Palaeorecords show that periods of long-term stability and periods of change are both normal. In addition, nonlinear abrupt climate changes can also occur. 
3. Concentrations of the greenhouse gas $\mathrm{CO}_{2}$ in the atmosphere have ranged from $\sim 3000 \mathrm{ppm}$ (parts per million) in the early Cretaceous 130 million years ago (Ma) to $\sim 1000 \mathrm{ppm}$ in the late Cretaceous (at $70 \mathrm{Ma}$ ) and early Cainozoic (at $45 \mathrm{Ma}$ ), leading to global temperatures $6^{\circ}$ or $7^{\circ} \mathrm{C}$ warmer than present. These high $\mathrm{CO}_{2}$ levels were products of Earth's biogeochemical cycles. During these times there was little or no ice on land. The $\mathrm{CO}_{2}$-rich, ice-free, warmer earlier periods created what is now referred to as a 'Greenhouse World'. The later parts of the Tertiary to the present: characterised by low $\mathrm{CO}_{2}$, abundant ice and cool temperatures, created what is referred to as an 'Icehouse World'. In the pre-industrial period of the early 19 th century the concentration of $\mathrm{CO}_{2}$ in the atmosphere was about $280 \mathrm{ppm}$. It is the speed with which greenhouse gas concentrations have increased since the early 19th century that is of great concern to scientists and policy makers.

4. The first continental-scale ice sheets formed on Antarctica around $34 \mathrm{Ma}$, most likely in response to a decline in atmospheric $\mathrm{CO}_{2}$ levels caused by a combination of reduced $\mathrm{CO}_{2}$ out-gassing from mid-ocean ridges and volcanoes and increased carbon burial stimulated by the erosion of newly rising mountains, the Himalayas. This decline resulted in a fall in global temperatures to around $4^{\circ} \mathrm{C}$ higher than today. At a maximum these early ice sheets reached the edge of the Antarctic continent, but were most likely warmer and thinner than today's ice sheets. Further sharp cooling took place at $\sim 14 \mathrm{Ma}$, probably accelerated by the growing physical and thermal isolation of Antarctica as other continents drifted away from it and the Antarctic Circumpolar Current (ACC) developed. At that time the ice sheet thickened to more or less its modern configuration. Alkenone-based $\mathrm{CO}_{2}$ reconstructions, from both high- and low-latitude sites in the Atlantic and Southern Oceans show that $\mathrm{CO}_{2}$ levels declined precipitously just prior to and during the onset of glaciations, confirming that $\mathrm{CO}_{2}$ played a dominant role in the inception of Antarctic glaciations (Pagani and others 2011). During the Pliocene, 5-3 Ma, mean global temperatures were $2-3^{\circ} \mathrm{C}$ above pre-industrial values, $\mathrm{CO}_{2}$ values may have reached $\sim 400 \mathrm{ppm}$, and sea levels were 15-25 m above today's. There is evidence for Pliocene WAIS collapse from the ANtarctic geological DRILLing (ANDRILL) project geological records, a feature also simulated by models (Pollard and DeConto 2009), in response to this warming.

5. The beginning of the cooling of the Southern Ocean is thought to date from the latest EoceneOligocene (circa $35 \mathrm{Ma}$ ). The establishment of the oceanic Polar Front created a barrier for migration of marine organisms between cold Antarctic and warmer waters at lower latitudes. Both these factors promoted adaptive evolution of the current Antarctic marine biota, and led to an overall moderate species diversity and regionally high biomass. The evolution of antifreeze proteins and the loss of haemoglobin in the fish group Notothenioidei are a prominent examples of diversific- ation (Matschiner and others 2011), and of evolution constrained by low thermal variability and tolerance (Beers and Sidell 2011) in a habitat characterised by temperatures close to freezing and high oxygen solubility. The development of sea ice played a large part in the success of Antarctic krill. These crustaceans have a high potential to disperse and show regional genetic variation and physiological plasticity similar to that of icefish. The various species of krill, not all of which are associated with sea ice, shaped the trophic structure of the Antarctic open ocean ecosystem and serve as a major food source for globally occurring seabirds and whales. Despite the Polar Front acting generally as a barrier to the dispersal of invertebrates and fish, some deep-sea and shelf inhabiting species still exchanged with northerly adjacent areas (Gutt and others 2010). During the late Quaternary there is evidence from bryozoan communities of a shallow seaway opening up between the Weddell and Ross Sea (Barnes and Hillenbrand 2010). ANDRILL results confirm the likely breakup of the WAIS at times during the Quaternary.

6. In an analogous fashion, circumpolar atmospheric circulation patterns isolated terrestrial habitats from potential sources of colonists from lower latitudes. In contrast with the marine environment, the combination of continental scale ice sheet formation and advance, and extreme environmental conditions, led to large-scale decline of pre-existing biota, and to evolutionary radiation amongst survivors. Fossil evidence shows the change from species associated with arid sub-tropical climates of Gondwanaland to cool temperate rainforest and then cold tundra when Antarctica was isolated by the opening of the Drake Passage and by the separation from Australia along the Tasman Rise. Most of these species are now extinct on the continent but, recent molecular, phylogenetic and fossil evidence suggests that some species groups have survived and adapted to the environmental changes including chironomid flies, mites, copepods, springtails, nematodes, diatoms, green algae (De Wever and others 2009), cyanobacteria, and heterotrophic bacteria (Peeters and others 2011). Many of these species are endemic to the continent.

\section{The last million years}

7. The long periods of cold of the Pleistocene glaciation (post $2.6 \mathrm{Ma}$ ) were subject to cycles of warming and cooling. Periodicities of 20,000, 41,000 and 100,000 years calculated from sediment and ice cores show that the cycles were paced by variations in the Earth's tilt, and its orbit around the Sun. These changes in incoming solar energy initiated feedback loops whereby small changes in temperature brought about larger changes in global atmospheric $\mathrm{CO}_{2}$ and methane, which enhanced the temperature rises by positive feedback. The climates of the two hemispheres were physically linked, warming or cooling the planet as a whole through the greenhouse effect. These processes led periodically to 
the development of short warm interglacial periods like that of the last 10,000 years. Over the past 450,000 years warm interglacial periods recurred at intervals of around 100,000 years. Prior to that, interglacials were less warm and before a million years ago they recurred at intervals of close to 40,000 years.

8. Palaeoclimate data, including Antarctic ice core records from glacial cycles over the last 800,000 years, show that $\mathrm{CO}_{2}$ and mean global temperature values ranged globally from $180 \mathrm{ppm}$ and $10^{\circ} \mathrm{C}$ in glacial periods to $280 \mathrm{ppm}$ and $15^{\circ} \mathrm{C}$ in interglacial periods. In Antarctica, the pre-industrial cold periods were on average $9^{\circ} \mathrm{C}$ colder than interglacials. Ice sheets in Antarctica and on the northern continents expanded in glacial periods, with sea level dropping by $120 \mathrm{~m}$ on average. Ice core data suggest a major control by the Southern Ocean on glacial-interglacial variations in atmospheric $\mathrm{CO}_{2}$ concentration, due to changes in $\mathrm{CO}_{2}$ solubility (less $\mathrm{CO}_{2}$ dissolves in warm seas), the efficiency of the 'biological pump' (which transfers $\mathrm{CO}_{2}$ in deep ocean waters during glacials, with most subsequently being stored in sediments) and changes in atmospheric and ocean circulation (the thermohaline conveyor belt sped up during interglacials, pushing more $\mathrm{CO}_{2}$-rich deep water to the surface), and in sea ice cover (the melting of sea ice during interglacials exposed upwelling deep water rich in $\mathrm{CO}_{2}$ to the atmosphere, encouraging ocean-atmosphere exchange).

9. Ice cores from Antarctica show that some interglacials in the last 400,000 years reached temperatures up to $5^{\circ} \mathrm{C}$ higher than they are today. Sea level was also higher in some of these interglacials, with possible extremes of 9 $\mathrm{m}$ higher in the last interglacial. Methane ranged between about 350 and $720 \mathrm{ppb}$. The last interglacial (around 130,000 years BP), when the temperature in Antarctica may have been as much as $5^{\circ} \mathrm{C}$ higher than in the preindustrial period is of particular interest. This warm Antarctic period coincided with the end of northern hemisphere deglaciation and preceded warmer than present Arctic conditions $\left(2-5^{\circ} \mathrm{C}\right.$ warmer than present day). The documentation of at least $6.6 \mathrm{~m}$ higher than present sea level, and a $67 \%$ probability that it exceeded $8.0 \mathrm{~m}$ during this time period (Kopp and others 2009) points to significant loss of Greenland and Antarctic ice. While climate models are able to capture the patterns of the orbitaldriven warming of the Arctic, they cannot represent the Antarctic warming during this interval unless they incorporate Greenland melt and possibly partial loss of the WAIS.

10. Antarctic ice cores reveal regional differences in the patterns of Antarctic millennial variability, especially between the Atlantic and Indo-Pacific sectors. Precise synchronisation of Greenland and Antarctic records shows that each abrupt climate event of the northern hemisphere has an Antarctic counterpart. However, warming in Antarctica precedes warming in Greenland, and Antarctic cooling precedes Greenland cooling, suggesting a bipolar seesaw pattern consistent with the theoretical consequences of reorganisations in the Atlantic Meridional Overturning Circulation (AMOC). Under this scenario, changes in the northward heat flux along the length of the Atlantic have impacts such that the Southern Hemisphere warms while the North Atlantic is cold, and cools when the North Atlantic is warm.

11. Diatom data from sediment cores show that at the Last Glacial Maximum (LGM), about 21,000 years BP, Antarctic sea ice was double its current extent in winter and also increased in extent in summer in at least some ocean sectors. In the Scotia Sea there is evidence that winter sea ice reached its maximum extent between 24,100 and 23,500 years BP, and summer sea ice between 30,800 and 23,500 years BP. This predates the LGM (Collins and others in press), and supports some models that show retreat of this ice before the LGM as a potential trigger for global deglaciation (Allen and others 2011). Related sea surface temperature calculations show that both the Polar Front and the sub-Antarctic Front shifted to the north during the LGM by between $2^{\circ}$ and $10^{\circ}$ in latitude from their present locations.

12. The Southern Ocean is almost certainly the main locus of changes that led to the large increase in atmospheric $\mathrm{CO}_{2}$ concentration between the LGM and the Holocene (Shakun and Carlson 2010). The cause is likely to have been a combination of changes in the strength of physical and biogeochemical processes. One recent study (Tschumi and others 2011) shows that Southern Ocean deep waters were stratified and depleted in radiocarbon during the last glacial period and through the early deglaciation up to $\sim 14.6 \mathrm{ka} \mathrm{BP}$. Afterwards deep ocean carbon was transferred to the surface and atmosphere via a Southern Ocean ventilation event consistent with the re-starting of the Meridional Overturning Circulation (MOC). This partially explains the elevation of atmospheric $\mathrm{CO}_{2}$ values between glacial and interglacial periods (Burke and Robinson 2012).

13. The expansion and contraction of Antarctica's ice sheets undoubtedly led to the local extinction of some biological communities on the Antarctic continent during glacial periods. The resulting present-day biodiversity consists of species that either survived the glacial maxima in refugia, then recolonised deglaciated areas, or arrived through inter- and post-glacial dispersal from lower latitude lands that remained ice free, or are present through a combination of both mechanisms (McGaughran and others 2010).

14. Continuous evolutionary development during glacial times in refugia, in combination with low extinction rates, is assumed to be a major driving force explaining the relatively high biodiversity of benthic (bottom-dwelling) marine organisms. Expansions and contractions of the sea ice had an impact on mammal and seabird distributions and general ecosystem functioning. These various expansions and contractions continued into the Holocene. 


\section{The Holocene}

15. The transition from the LGM to the present interglacial period (the Holocene, beginning around 12,000 years BP) was the last major global climate change event. Ice core and geological evidence from land in Antarctica shows a marked warming period in the Holocene, between 11,500-9,000 years BP; this is a period of maximum insolation for the Antarctic determined from astronomical calculations. Some marine records show evidence of a marine optimum between about 7,000-3,000 years BP, and many terrestrial records show evidence of an optimum between 4,000-2,000 years BP. These warm periods were likely to have raised temperatures by no more than around $0.5-1{ }^{\circ} \mathrm{C}$.

16. The ice core record indicates changes in atmospheric circulation in the Antarctic. They suggest strengthening of the Southern Hemisphere westerlies at 6,000 years BP followed by abrupt weakening at 5,4005,200 years BP. They also suggest intensification of the westerlies and the Amundsen Sea Low pressure cell at around 1,200 years BP (Mayewski and others 2009).

17. There is no evidence in Antarctica for a precise equivalent to the northern hemisphere Medieval Warm Period (MWP), but some periods of the last 1000 years were likely to have been as warm or even warmer than the late 20th century (Goosse and others 2012). There is also some evidence for a cool event equivalent in time to the northern hemisphere's Little Ice Age (LIA) in some of the ice core data (Bertler and others 2011). Some ice core records suggest that the LIA is the most prominent event of the last $\sim 5,000$ years in Antarctica (Mayewski and others 2004). Terrestrial and marine geological records generally do not show convincing evidence of either an MWP or an LIA occurring at the same time as in the northern hemisphere and no MWP or LIA is evident in the James Ross Island ice core (Mulvaney and others 2013)

18. Associations between changes in solar energy output and climate have been debated for many years. Satellite observations have demonstrated that the association is not a consequence of simple heating of the upper atmosphere. However, associations have been demonstrated between changes in solar energy output, at least for solar cycle duration, and in ozone concentration in the lower stratosphere. Ice core records suggest a link between solar energy output changes and changes in atmospheric circulation through changes in ozone concentration. It is intriguing to consider that stratospheric ozone has played an important role in both naturally varying changes in atmospheric circulation and the recent more dramatic shifts in atmospheric circulation associated with the anthropogenic Antarctic ozone hole (Mayewski and others 2006).

19. The main biological changes occurring during the Holocene involved the recolonisation of habitats as the ice sheet retreated, both by species that had survived the glaciations in refugia on the continent and continental shelf and by others originating from lower lat- itude landmasses. Species assemblages and distributions have also responded to periods of positive and negative temperature changes in the Holocene, in particular, those species with narrow ecological ranges or sensitivity to physical factors such as the changing extent of sea ice (penguins and seals). These responses provide insight for predicting changes under future warming scenarios.

\section{Changes during the instrumental period}

20. The instrumental period is considered to have begun in the Antarctic with the International Geophysical Year of 1957-1958. Here we discuss key changes in the atmosphere, ice and ocean systems, and the biosphere since that time.

\section{The large scale circulation of the atmosphere}

21. The major mode of variability in the atmospheric circulation of the high southern latitudes is the Southern Hemisphere Annular Mode (SAM). This is a circumpolar pattern of atmospheric mass displacement in which the intensity and location of the gradient of air pressure between mid-latitudes (higher pressure) and the Antarctic coast (lower pressure) changes in a non-periodic way over a wide range of time scales from days to years. Over the past 50 years the SAM became more positive (stronger circumpolar westerly winds) in the austral summer and autumn, as pressure dropped around the coast of the Antarctic and increased at mid-latitudes (Thompson and others 2011 and references therein). Since the late 1970 s the strength of the westerly winds over the Southern Ocean has increased by 15-20\% (Korhonen and others 2010; Turner and Marshall 2011) and has resulted in a poleward migration of the westerlies by $1-2^{\circ}$ of latitude. The change in the SAM has led to a decrease in the annual and seasonal numbers of cyclones south of $40^{\circ} \mathrm{S}$. There are now fewer but more intense cyclones in the Antarctic coastal zone between 60 and $70^{\circ} \mathrm{S}$, except in the Amundsen-Bellingshausen Sea region (Simmonds and others 2003). The combination of the stronger westerly winds around the continent, with the off-pole displacement of Antarctica, has led to a deepening of the Amundsen Sea Low, with consequent effects on temperature and sea ice in the coastal region of West Antarctica. These increased wind speeds and the decreasing ozone concentration have been linked with decreased growth rates of plants (Clarke and others 2012) and biodiversity changes in lakes (Hodgson and others 2006) in East Antarctica. From ice core records it appears that intensification of the westerlies and the Amundsen Sea Low started as early as the late 1800s, but in recent decades the intensification associated with ozone depletion is more pronounced (Dixon and others 2012).

22. The observed trend in the SAM has been largest during the austral summer. It is believed to be driven primarily by the development of the Antarctic ozone hole (Thompson and others 2011 and references therein). Evidence that increased greenhouse gases have played 
a role is conflicting (Treguier and others 2010). The ozone hole forms in the austral spring; at that time of year the loss of stratospheric ozone cools the Antarctic stratosphere, so increasing the strength of the polar vortex. This is a large high altitude cyclonic circulation that forms in winter in the stratosphere above the Southern Ocean around Antarctica. These anomalies precede similarly signed anomalies in the tropospheric circulation during summer, that is a strengthening of the southern hemisphere circumpolar winds from the lower stratosphere to the surface due to the ozone hole. The variability of the SAM and the influence of a range of forcing factors has been examined by Fogt and others (2009).

23. In recent decades there have been more frequent and more intense El Niño events. During some of them a signal of the El Niño cycle can be seen in the Antarctic. Ice core records may preserve evidence of El Niño-Southern Oscillation (ENSO) signals as far south as the South Pole (Meyerson and others 2002). There is no evidence that this trend has affected long term climate trends in the Antarctic. In addition, atmospheric circulation and temperature reconstructed from ice cores show large inter-annual to decadal variability, with the dominant pattern being anti-phase anomalies between the continent and both West Antarctica and the Antarctic Peninsula, which is associated with the SAM during the recent period of observations. There is decadal variability of the ENSO teleconnection to the Antarctic and interactions with the SAM (Fogt and Bromwich 2006).

\section{Atmospheric temperatures}

24. Surface temperature trends show significant warming across the Antarctic Peninsula and to a lesser extent the rest of West Antarctica since the early 1950s, with little change across the rest of the continent (Turner and others 2005). The largest warming trends have been on the western and northern parts of the Antarctic Peninsula. There Faraday/Vernadsky Station, at $65.4^{\circ} \mathrm{S}$ on the western peninsula, has experienced the largest statistically significant $\left(<5 \%\right.$ level) trend of $+0.54^{\circ} \mathrm{C}$ per decade for the period 1951-2011; the warming has taken the form of a reduction in the number of extreme cold winters at the peninsula (Turner and others 2012). The longest temperature record at high southern latitudes is from Orcadas on Laurie Island, South Orkney Islands, and it shows a warming of $+0.21^{\circ} \mathrm{C}$ per decade since 1904 . The western peninsula warming has been largest during the winter, with temperatures at Faraday/Vernadsky during that season increasing by $+1.01^{\circ} \mathrm{C}$ per decade from 1950 2011. There is a high correlation during the winter between sea ice extent a few hundred kilometers from the station and surface temperatures (Turner and others 2012), suggesting more sea ice during the 1950s-1960s and a reduction since then. Over 2000-2011 there was a slight drop in the annual mean temperature at stations on the Antarctic Peninsula north of Faraday/Vernadsky
(Blunden and Arndt 2012). Analysis of an ocean sediment core that spanned the late Holocene suggested that atmospheric forcing through an increasing frequency of El Niño events and greater solar insolation played a greater part in modulating peninsula temperatures compared to ocean forcing (Pike and others 2013).

25. Temperatures on the eastern side of the Antarctic Peninsula have risen most during the summer and autumn (at $+0.39^{\circ} \mathrm{C}$ per decade from1946-2011 at Esperanza), linked to the strengthening of the westerlies that took place as the SAM shifted into its positive phase, primarily as a result of the ozone hole (Thompson and others 2011 and references therein). Stronger westerly winds now bring warm, maritime air masses across the Peninsula to the low-lying ice shelves on the eastern side with the Foehn effect adding to the warming of the air masses coming over the peninsula (Marshall and others 2006).

26. There are no staffed stations on the West Antarctic ice shelf with long, continuous meteorological records. However, a number of recent studies based on satellite observations, automated weather station (AWS) measurements, reanalysis fields and the available station data have suggested that the area has experienced a warming over the last few decades. Steig and others (2009) used satellite and AWS data to estimate a warming of $0.1^{\circ} \mathrm{C}$ per decade since the late 1950 s, especially in winter and spring, although the study of O'Donnell and others (2011) put the warming at slightly less than this. The incomplete record from Byrd station has recently had the data gaps filled through the use of reanalysis fields and interpolation, with the resulting temperature time series suggesting that the location has warmed by $2.4 \pm$ $1.2^{\circ} \mathrm{C}$ over 1958-2010 (Bromwich and others 2013). This would establish the region as one of the most rapidly warming areas on Earth. Ice core data from the Siple Dome suggest that this warming began around 1800 . Recent warming across continental West Antarctica has been linked to sea surface temperature changes in the tropical Pacific, especially during the spring (Schneider and others 2012). Over the past 30 years, anomalous sea surface temperatures in the central tropical Pacific have generated an atmospheric Rossby wave response that influences atmospheric circulation over the Amundsen Sea, causing increased advection of warm air to the Antarctic continent. General circulation model experiments also link the central tropical Pacific with the observed high latitude response. By affecting the atmospheric circulation at high southern latitudes, increasing tropical sea surface temperatures may account for West Antarctic warming through most of the 20th century (Ding and others 2011).

27. On the plateau, Amundsen-Scott Station at the South Pole shows a statistically significant cooling in recent decades, interpreted as due to fewer warm maritime air masses penetrating into the interior of the continent. This could also be a manifestation of the low-pressure anomaly that now propagates downward from the ozone hole. 
28. Temperatures reconstructed from ice cores show large inter-annual to decadal variability, with one reconstruction suggesting that Antarctic temperatures increased on average by about $0.2^{\circ} \mathrm{C}$ since the late 19 th century (Schneider and others 2006). Three ice borehole temperature time series from the peninsula, West Antarctica and East Antarctica all show a significant warming in recent decades. The East Antarctic data (Muto and others 2011) covered the last 20-50 years on the Dronning Maud Land divide, a region without any other long-term records. Warming of $0.1-0.2^{\circ} \mathrm{C} /$ decade was indicated by both Monte Carlo and inverse methods. The results from the peninsula (Zagorodnov et and others 2012) match well with other ice core chemistry and borehole records from the region, showing a low in mean annual temperature around 1930 then increasing at $\sim 0.33^{\circ} \mathrm{C} /$ decade until about 1995, and then a slight flattening or cooling of $\sim 0.5^{\circ} \mathrm{C}$ in the most recent decade. The West Antarctica data (Orsi and others 2012) show that cool conditions prevailed on the WAIS during the Little Ice age period, and that warming began around 1800 and continued through the past 100 years. A sharp increase in the rate of warming in the past 20 years, to $\sim 0.7^{\circ}$ $\mathrm{C} /$ decade, is indicated by the data.

29. Antarctic radiosonde temperature profiles show that the atmosphere has warmed at the mid-tropospheric level and that the stratosphere above it has cooled over the last 50 years (Screen and Simmonds 2012). This pattern would be expected from increasing greenhouse gases. Over the last 50 years the tropospheric warming in winter has been the largest on Earth at $500 \mathrm{hPa}$ (Turner and others 2006). It may, in part, be a result of the insulating effect of greater amounts of polar stratospheric clouds during the winter (Lachlan-Cope and others 2009).

30. Over Antarctica, there has been long-term stratospheric cooling of annual mean temperatures of $\sim 0.5^{\circ} \mathrm{C}$ per decade (between 1979 and 2007) and there are tentative indications of $\sim 1^{\circ} \mathrm{C}$ per decade cooling in the mesosphere $(\sim 87 \mathrm{~km})$. Various data series show a mean solar cycle variation (solar maximum minus solar minimum) in temperature in the stratosphere of between $0.1^{\circ} \mathrm{C}$ and $1^{\circ} \mathrm{C}$, and in the mesosphere at $\sim 87 \mathrm{~km}$ of typically between $3^{\circ} \mathrm{C}$ and $6^{\circ} \mathrm{C}$. There is growing evidence (Seppälä and others 2009) that solar variability has some influence on Antarctic regional climate, though the chain of causality has yet to be established and the effects fully quantified. To extract the signal with a high level of confidence, long well-populated datasets are required throughout the atmosphere and these have been limited in Antarctica due to the sparse instrumentation and shortness of the records. Solar UV variability brings about changes in stratospheric temperature and ozone, which, through subsequent changes in planetary wave motion and the SAM, can alter stratosphere-troposphere coupling, and hence tropospheric wind variability. Antarctica is unique in that, because of the dynamic stability of the southern polar vortex, solar wind variability strongly influences the amount of NOx entering the stratosphere from above.

31. Antarctic observations of hydroxyl airglow in the mesopause region ( $87 \mathrm{~km}$ altitude) show annual average cooling trends of $1-2^{\circ} \mathrm{C}$ per decade (over the last 2 decades) with a strong seasonal variation (French and Klekociuk 2011). Maximum cooling rates of around $4{ }^{\circ} \mathrm{C}$ per decade occur in August-September at the time of the ozone depletion, with little or no trend over the winter months. These long-term trends are superimposed on a solar cycle response of $4-5^{\circ} \mathrm{C}$ per 100 solar flux units. This response appears to be stronger over the Antarctic than at low latitudes or in the northern hemisphere (Beig and others 2008).

32. An updated set of time series of derived aerosol optical depth (AOD) from a number of Antarctic stations has been analysed to determine the long-term variations. The Antarctic data-set comprises sun-photometer measurements made at Mirny (1982-2009), Neumayer (19912004), Terra Nova Bay (1987-2005), and at South Pole (1977-2010). The long-term variation in Antarctic AOD was estimated to be stable, within $\pm 0.10 \%$ per year, at the three coastal sites. At South Pole there has been a small decrease, possibly due to the formation of thin stratospheric layers of ageing volcanic particles (Tomasi and others 2012).

\section{Snowfall}

33. On average, about $7 \mathrm{~mm}$ global sea level equivalent ( 2,500 Gt ice equivalent mass) falls as snow on Antarctica each year, but there has been no statistically significant change since 1957 (Monaghan and others 2006). Snowfall trends vary from region to region, with the greatest accumulation in the Antarctic Peninsula and coastal West Antarctica, adjacent to the Amundsen Sea Low, which advects warm, moist air from lower latitudes. Integrated over the entire ice sheet, snowfall shows modest interannual variability (standard deviation of 114 Gt per yr), yet a pronounced seasonal cycle (standard deviation of about $30 \mathrm{Gt}$ per month). Snowfall has increased on the western side of the peninsula, where it has been linked to decreases in Adélie penguin populations, which prefer snow-free nesting habitat and nest earlier than gentoo or chinstrap penguins when there is now an increased likelihood of snow burying nests. There is little evidence of broad regional increases in East Antarctic accumulation.

34. Recent research has highlighted the interaction between the wind field and snowfall, and the presence of large 'hiatus' areas in East Antarctica (Arcone and others in press). Such areas combine to cover up to $10 \%$ of the plateau surface above $1500 \mathrm{~m}$, and result in a net reduction of the estimate of true current accumulation of East Antarctica (from models or from interpolated observations) of 40-80 Gt. This has significant implications for mass balance studies.

35. The time-series of temperature and snow accumulation rates reconstructed from the data from eight snow 
pits and four shallow cores drilled near Vostok Station show that the regional climate is dominated by the quasiperiodic oscillations of these parameters with a period of 40-50 years. Average accumulation rate varied from 1.2 to $3.0 \mathrm{~g} / \mathrm{cm}^{2}$ with an average of $2.01 \mathrm{~g} / \mathrm{cm}^{2}$. Temperature varied from $-56.5^{\circ} \mathrm{C}$ to $-54.0^{\circ} \mathrm{C}$. The cyclical character of the changes in the region during the last three centuries is confirmed by the temperature data in the upper $100 \mathrm{~m}$ of ice as well as by instrumental measurements of air temperature for the recent decades (Ekaykin and others 2011). The zonal and meridional components of the circulation to a large extent dictate the temperature and precipitation anomalies. In the early 1970s the sign of the relationship between many climatic parameters changed, which is probably related to the rearrangement of the climate system of the southern hemisphere. The data suggest that during the past 350 years such events have happened at least five times. (Kozachek and others 2011).

\section{The Antarctic ozone hole}

36. Stratospheric ozone amounts began to decline in the 1970s, following widespread releases of chlorofluorocarbons (CFCs) and halons into the atmosphere that destroyed virtually all ozone between heights of 14 and $22 \mathrm{~km}$ over Antarctica each spring and early summer. Owing to the success of the Montreal Protocol, the amounts of ozone-depleting substances in the stratosphere are now decreasing by about $1 \%$ per year. As a result the size and depth of the ozone hole have stabilised, but are not yet decreasing. The interannual variability of the ozone hole remains largely controlled by meteorological factors in the stratosphere. Model calculations suggest that the decline in Antarctic ozone is linked to marked changes in surface climate. See Thompson and others 2011 and references therein for details).

\section{Terrestrial biology}

37. A meta-analysis of the response of polar plants to UV-B radiation under field conditions confirms that elevated UV-B exposure leads to increasing concentrations of UV-B protective compounds in photosynthetic tissues, reduced above-ground biomass and plant height and increased DNA damage. The sensitivity of plant growth to ozone-induced variations in UV-B radiation indicates an approximate $1 \%$ reduction in growth for each $3 \%$ increase in weighted UV-B irradiance (Newsham and Robinson 2009). Based on this analysis, Ballare and others (2011) estimated that, for areas subject to substantial ozone depletion, for example the southern tip of South America (at $55^{\circ} \mathrm{S}$ ) where ozone depletion has led to a $20 \%$ increase in the summertime levels of UV-B radiation, the resulting decrease in plant growth rate over the past three decades would be about $6 \%$.

38. The clearest example of Antarctic terrestrial organisms responding to climate change is given by the two native flowering plants (Deschampsia antarctica and Colobanthus quitensis) in the maritime Antarctic, which have increased in abundance at some sites. Warm- ing encourages the growth and spreading of established plants, increased seed set and increased establishment of seedlings. Changes in temperature and precipitation have also increased biological production in lakes and altered species assemblages, mainly due to decreases in the duration and extent of lake ice cover. Some lakes have become more saline due to drier conditions. Shorter term (decadal) decreasing temperature in the Dry Valleys reduced primary production in lakes and the number of soil invertebrates (Doran and others 2002). These ecosystems might be especially sensitive to climate change and respond differently at different temporal scales (Nielsen and others 2011). As noted earlier in point 21, ozone depletion and increasing wind speeds have also impacted the terrestrial biota.

\section{The terrestrial and marine cryosphere}

39. Ice shelves along the Antarctic Peninsula have changed rapidly in recent decades, with episodes of retreat, breakup and collapse occurring on both side of it. The overall reduction in total ice shelf area during the last five decades has been estimated to be over $28,000 \mathrm{~km}^{2}$ (Cook and Vaughan 2010). Loss of ice on the eastern side results predominantly from warm air being brought over the peninsula by the stronger westerlies forced by changes in the SAM and, ultimately, driven by the development of the ozone hole. Ice shelf thinning has been attributed both to surface and sub-surface melting (Scambos and others 2000; Pritchard and others 2012). In the northern Antarctic Peninsula surface warming began approximately 600 years ago (Sterken and others 2012), so the ice shelves were preconditioned for collapse as the rate of warming intensified during the last 100 years (Mulvaney and others 2012). Ice-shelf collapse is thought to result from hydro-fracture of water-filled crevasses combined with changes in firn density and ice thickness as a result of local changes in surface mass balance and rates of basal melt. Retreat of ice shelves in the Antarctic during the instrumental period appears to be synchronous with those in the Arctic (Hodgson 2011). Removal of ice shelves has led to speed-up of upstream glacier flow from inland due to reduction in buttressing forces.

40. Some formerly snow- and ice-covered subAntarctic islands are now increasingly snow-free during the summer. Brown Glacier on Heard Island lost 29\% of its surface area between 1947 and 2004, causing the formation of several lagoons. On South Georgia, 97\% percent of 103 coastal glaciers surveyed from the 1950s to the present have retreated and the average rate of retreat has increased from $8 \mathrm{~m} \mathrm{year}^{-1}$ in the $1950 \mathrm{~s}$ to $35 \mathrm{~m} \mathrm{year}^{-1}$ at present (Cook and others 2010). Further south in the South Shetland Islands, the ice-covered area of King George Island decreased by $1.6 \%$ during 2000 2008 (Ruckamp and others 2011), a rate of loss similar to that of the period 1956-1995, when the ice-covered area decreased by $7 \%$.

41. Of the 244 marine-terminating glaciers that drain the northern sector of the Antarctic Peninsula ice cap, 212 
(87\%) showed overall retreat since 1953 . The remaining 32 glaciers $(13 \%)$ have shown small advances. Studies analysing both marine-terminating and land-terminating glaciers in the region also show an overall trend of retreating ice fronts. There is a range of variations throughout the study area including stationary ice fronts on the northwestern coast of the peninsula (Rau and others 2004). The rates of recession, however, seem to be declining. In a study of 194 glaciers on Trinity Peninsula, Vega Island and James Ross Island, Davies and others (2012) show that, over 1988-2001, 90\% of glaciers receded, while for 2001-2009, 79\% receded. Glaciers on the western side of Trinity Peninsula retreated relatively little. The total glaciated area in the northern Antarctic Peninsula declined by $11.1 \%$ during 19882001 and by $3.3 \%$ during 2001-2009. The tidewater glaciers on the Eastern Trinity Peninsula, and the landterminating glaciers on James Ross Island also retreated fastest in the period 1988-2001. Only the large tidewater glaciers on James Ross Island are declining in areal extent at faster rates after 2001. A recent study of the mass balance of the different sectors of the Antarctic based on the various forms of satellite data (Shepherd and others 2012) found that over 1992-2011 the mass of the Peninsula changed by $-20 \pm 14 \mathrm{Gt}_{\text {year }}{ }^{-1}$.

42. The Amundsen Sea sector of West Antarctica is the most rapidly changing region of the Antarctic ice sheet (Jenkins and others 2010). The grounding line at Pine Island has retreated and the Pine Island glacier is now moving at speeds $60 \%$ higher than in the 1970 s. The Thwaites Glacier and four other glaciers in this sector show accelerated thinning. Smith Glacier has increased flow speed $83 \%$ since 1992. Pine Island and adjacent glacier systems are currently more than $40 \%$ out of balance, discharging $280 \pm 9 \mathrm{Gt}$ of ice per year, while they receive only $177 \pm 25$ Gt per year of new snowfall. For the WAIS as a whole the Shepherd and others (2012) study found that over 1992-2011 the mass of the ice sheet changed by $-65 \pm 26 \mathrm{Gt}$ year $^{-1}$.

43. The current changes in the Amundsen Sea embayment region could represent a continuing response to historical forcing, a more direct result of increased delivery of warm Circumpolar Deep Water (CDW) (Jacobs and others 2011) to the sub-ice-shelf cavities over recent decades, or, most likely, a combination of the two. Although changes in atmospheric circulation appear to be responsible for driving more $\mathrm{CDW}$ onto the continental shelf, there is no unambiguous link yet established with the more positive SAM index. The Amundsen Sea Low has been implicated as a causal factor in controlling the flux of CDW (Thoma and others 2008), and changes in central tropical Pacific sea surface temperatures may be more important in triggering the critical responses in the Amundsen Sea circulation (Steig and others 2012).

44. Changes are less dramatic across most of the East Antarctic ice sheet, with the most significant changes close to the coast. The ice sheet shows interior thickening at modest rates and a mixture of moderate thickening and thinning among the fringing ice shelves (Pritchard and others 2012). Melt trends from passive microwave data show less melt in coastal regions in recent years (2008, 2009). These anomalies are linked to trends in the summer SAM, which have suppressed warming over much of Antarctica during the satellite era. The Shepherd and others (2012) study found that for 1992-2011 the mass of the East Antarctic ice sheet changed by $+14 \pm$ $43 \mathrm{Gt}^{\text {year }^{-1} \text {. }}$

45. The Antarctic ice sheet provides a remarkable record of background levels of gases and pollutants. Pollutants in the Antarctic have been shown to be transported large distances. For example, black carbon measured in Antarctic ice cores comes from southern hemisphere biomass burning (Wang and others 2010). Lake sediments also provide a temporal record of contamination from high temperature fossil-fuel combustion sources (Rose and others 2012).

\section{Sea level changes}

46. Data from tide gauges and satellite altimeters suggest that in the 1990s-2000s global sea level rose at a rate of $3.3 \mathrm{~mm}$ per year (Woodworth and others 2011), which is higher than predicted from earlier IPCC projections. The recent study of Shepherd and others (2012), discussed above, reconciled the various satellite-derived estimates of changes in the mass of the Antarctic ice sheet and also estimated the contribution to sea level rise. They found that over the period 1992-2011 the Antarctic Peninsula, West Antarctica and East Antarctica have respectively contributed $+0.05 \pm 0.04,+0.18 \pm 0.07$ and $-0.04 \pm$ $0.12 \mathrm{~mm}$ per year to global sea level rise. Combined this gives a contribution from the whole Antarctic ice sheet of $+0.20 \pm 0.15 \mathrm{~mm}$ per year, which compares to $+0.39 \pm 0.14 \mathrm{~mm}$ per year from the Greenland ice sheet.

\section{The Southern Ocean}

47. In surface waters, change is difficult to detect because an intensive seasonal cycle can induce large errors when there are only a few samples. However, around South Georgia observations exist since 1925 that are frequent enough to resolve the annual cycle, and these reveal a warming averaging $2.3^{\circ} \mathrm{C}$ over 81 years in the upper $150 \mathrm{~m}$ (Whitehouse and others 2008). This is about twice as strong in winter as in summer, and is thought to be caused by a combination of the particular location of the island with respect to the footprint of the intensifying SAM over the Southern Ocean, and advection of warmed waters from upstream in the Southern Ocean circulation. There is also a strong warming of the upper ocean west of the Antarctic Peninsula, where temperatures have risen by nearly $1.5^{\circ} \mathrm{C}$ since the $1950 \mathrm{~s}$, accompanied by a marked summertime salinification caused by changes in the rate of sea ice production (Meredith and King 2005). In coastal areas like Potter Cove (King George Island, South Shetlands), a circa 20 year data series showed sea surface temperatures increased during summers by 
$0.36^{\circ} \mathrm{C}$ per decade (Schloss and others 2012). A significant portion of the ocean warming at the western Antarctic Peninsula is believed to be caused by nearsurface ocean-atmosphere-ice interactions (Meredith and King 2005). In addition there has been a marked increase in the supply of warm CDW from the ACC onto the shelf in recent decades, providing heat and nutrients to increase retreat of the cryosphere and fuel biological production (for example Martinson and others 2008).

48. The waters of the ACC have warmed more rapidly than the global ocean as a whole, increasing by $0.06^{\circ} \mathrm{C}$ per decade at depths between $300-1000 \mathrm{~m}$ over the 1960 s to $2000 \mathrm{~s}$, and by $0.09^{\circ} \mathrm{C}$ per decade since the 1980s. The warming is more intense on the southern side of the ACC than north of it. A maximum increase of $0.17^{\circ} \mathrm{C}$ per decade was found in Upper Circumpolar Deep Water at depths of 150-500 $\mathrm{m}$ on the poleward side of the Polar Front (Gille 2002; Böning and others 2008). These changes are possibly consistent with a southward shift of the ACC in response to a southward shift of the westerly winds driven by enhanced greenhouse forcing and the loss of stratospheric ozone, however such a shift is hard to prove definitively, and previous assertions may have misinterpreted the satellite information on which they were based (Graham and others 2012 and references therein). Other causes for these changes have been proposed. North of the ACC a significant freshening of 0.01 salinity units per decade is observed since the 1980s (Böning and others 2008). There is no evidence for an increase in ACC transport, despite the strengthening SAM (Meredith and others 2011). Instead, recent studies suggest that an increase in wind forcing causes an increase in the intensity of Southern Ocean eddies rather than a sustained acceleration of the zonal transport. This then acts to increase the southward transport of heat in the Southern Ocean and hence may be a causal factor in the observed warming (Hogg and others 2008; Meredith and Hogg 2006).

49. Changes are evident in the character of the dense water (the Antarctic Bottom Water, AABW) formed around Antarctica and exported to lower latitudes. Globally there has been a contraction of $\mathrm{AABW}$ relative to a given temperature or density surface though the degree to which this is indicative of warming versus a reduction in production rate is still being investigated (for example Purkey and Johnson 2012). AABW warming has been strongest in the South Atlantic sector, but is significant at all longitudes (Purkey and Johnson 2010). In addition, marked freshenings of AABW have been observed in the Ross Sea and Indian/Pacific sectors of the Southern Ocean (Jacobs and others 2002; Rintoul 2007). Recent indications are that the AABW exported from the Weddell Sea is also freshening decadally, due most likely to loss of the Larsen ice shelves and accelerated glacier flow, and consistent with the reported freshening of shelf waters on the eastern side of the Antarctic Peninsula (Hellmer and others 2011).

\section{Biogeochemistry}

50. The Southern Ocean ventilates the global oceans and regulates the climate system by taking up and storing heat, freshwater, $\mathrm{O}_{2}$ and atmospheric $\mathrm{CO}_{2}$. Between 1991 and 2007 the concentration of $\mathrm{CO}_{2}$ in the ocean increased south of $20^{\circ} \mathrm{S}$ in the southern Indian Ocean. At latitudes poleward of $40^{\circ} \mathrm{S}, \mathrm{CO}_{2}$ in the ocean increased faster than it did in the atmosphere, suggesting that the ocean became less effective as a sink for atmospheric $\mathrm{CO}_{2}$. The stronger westerly winds lead to surface oceanic water being enriched with 'natural' $\mathrm{CO}_{2}$ from upwelling deep waters (Le Quéré and others 2007). This saturates the carbon reservoir of the surface water limiting its ability to absorb carbon dioxide from the atmosphere. These changes are linked to the increase in wind strength driven by the more positive SAM. Ocean eddies will partially compensate for the increase in wind-driven overturning, however, a net increase in upwelling of a size important for the drawdown of anthropogenic carbon still results (Meredith and others 2012). An increase in the ocean's $\mathrm{CO}_{2}$ content releases $\mathrm{H}+$ ions and so makes the ocean more acidic. In addition to $\mathrm{CO}_{2}$ changes, the Southern Ocean's $\mathrm{O}_{2}$ content has also changed, showing some of the most significant decreases of any region of the global ocean (Helm and others 2011). This is believed to be caused primarily by a reduction in water mass formation rates caused by increasing stratification as a result of surface ocean warming. Regional changes in biogeochemistry are also becoming apparent in the Southern Ocean. Particularly significant is the observation of changed phytoplankton communities in response to ocean climate change at the WAP (Montes-Hugo and others 2009). These authors used three decades of satellite and field data to demonstrate a significant decline in summertime surface Chlorophyll-a, with the largest decreases equatorward of $63^{\circ} \mathrm{S}$ and with partiallycompensating increases occurring farther south. The latitudinal variation in Chlorophyll-a trends reflects shifting patterns of ice cover, cloud formation, and windiness affecting water-column mixing.

\section{Sea ice}

51. For the first half of the 20th century, ship observations suggest that the extent of sea ice around the Antarctic was greater than seen in recent decades, although the validity of such observations has been questioned. The sea ice extent data derived from satellite measurements from 1979-2010 show a positive trend of the annual mean Antarctic ice extent of $1.3 \%$ per decade (significant at $<1 \%$ level). The trends in ice concentration have been linked to trends in ice motion, with wind-driven changes in ice advection being the dominant factor in driving the Antarctic sea ice extent increase (Holland and Kwok 2012). The extent of Antarctic sea ice reached a new record maximum for the satellite era in 2012. The trend has been positive in all sectors except the Bellingshausen Sea, where sea ice extent has been significantly reduced. The greatest increase, at around $4.5 \%$ per decade, has 
been in the Ross Sea. The Bellingshausen and Ross Seas have experienced increases and decreases respectively in the length of the sea ice season (Stammerjohn and others 2008). The reduction of ice extent in the Bellingshausen Sea and its increase in the Ross Sea have been influenced by a deepening of the Amundsen Sea Low. In addition, Comiso and others (2011) linked the variability in ice extent in the Ross Sea to changes in the SAM and secondarily to the Antarctic Circumpolar Wave. Warm winds brought south by the Amundsen Sea Low impede the advance of the sea ice to the west of the peninsula, while cold, southerly flow west of the low over the Ross Ice Shelf enhances ice production over the Ross Sea. The reasons for the overall increase in Antarctic sea ice extent over the last 30 years are still under debate. Turner and others (2009b) suggested that the loss of stratospheric ozone during the spring had played a significant role in the ice increase by increasing the strength of the Amundsen Sea Low and its associated surface winds. However, the modelling work of Sigmond and Fyfe (2010) suggested that the loss of ozone would result in a decrease of sea ice extent. Zhang (2007) and Liu and Curry (2010) suggested that ocean change and an intensification of the freshwater cycle, thus freshening the waters of the Ross Sea, had played a part in increasing the sea ice cover.

52. Analysis of an Antarctic Peninsula ice core suggested that sea ice decline in the Bellingshausen Sea is part of a trend that has occurred throughout the 20th century. It may reflect a progressive deepening of the Amundsen Sea Low due to increasing greenhouse gas concentrations and, more recently, stratospheric ozone depletion. This longer term perspective contrasts with the small increase in Antarctic sea ice that is observed in post-1979 satellite data (Abram and others 2010).

\section{Marine biology}

53. The Southern Ocean ecosystem was significantly disturbed by whaling during the early part of the 20th century, by sealing before that and by fishing since the mid-1900s. About 300,000 blue whales were killed, equivalent to more than 30 million tonnes of biomass. Stocks of humpback, fin, sei, and minke whales were similarly driven to near extinction (Simmons and Eliott 2009). The krill stock was expected to increase due to this reduction in grazing pressure, but it did not, possibly because it has been reduced by the reduction in sea ice in the Bellingshausen Sea. While predation by seals and birds increased, the total bird and seal biomass remains only a fraction of that of the former whale population. Humpback whales seem to be rapidly recovering (Ainley and others 2010), whilst populations of other species remain low. Benthic communities and fish are expected to slowly recover from bottom fishing impacts, although evidence supporting this is not yet forthcoming. In case of further warming, commercially exploitable fishes, such as the southern blue whiting, could extend their distribution range into the Antarctic
(Agnew and others 2003). A single record of a juvenile spider crab (Hyas araneus) provides the only evidence of an assisted transfer, possibly by ballast water to the Antarctic. For further examples of similar processes see Aronson and others (2011).

54. The marine ecosystem of the Western Antarctic Peninsula (WAP) has been impacted over distances of 1000-200 km (McClintock and others 2008) by a significant reduction in the sea ice habitat by 85 days per year, and by secondary effects on the food web, or by a combination of both. These changes include:

reduction of primary production in the ice;

increases and decreases of primary production in the water column;

a shift in phytoplankton from diatoms to smaller species (Schloss and others 2012);

increases of lantern-fish and salp biomass;

an overall decrease of krill due to recruitment failures; local increases of krill and humpback whales (Nowacek and others 2011);

a decrease in Antarctic silver fish, a keystone species; shifts in the ranges of Adélie, gentoo, and chinstrap penguin populations to the south (Stokstad, 2007), with a net reduction in the numbers of Adélies and gentoos (Trivelpiece and others 2011);

shifts in the range of southern elephant seal populations to the south (Costa and others 2010), and decreases in the north of their range (McIntyre and others 2011);

increased mortality in benthic organisms due to ice scouring (Barnes and Souster 2011);

recent identification of large densities of king crabs in the Palmer Deep (a deep basin within the Antarctic Peninsula continental shelf) and elsewhere.

It is suggested that this indicates migration up-slope from the deep Southern Ocean benthos as the continental slope waters have warmed (Smith and others 2012), although no earlier survey or other data exist against which to test this hypothesis. Given that Antarctic shelf faunas are not adapted to depradation by crabs, changes in benthic community structure might result if these animals eventually colonise the continental shelf. However, it should be noted that such crabs are present on the slightly warmer shelves of island groups further north but still south of the ACC, such as South Georgia, where they apparently co-exist within diverse benthic communities that have very large compositional overlap with those of the Antarctic Peninsula in particular

55. Beyond the WAP there have been other changes to the marine ecosystem:

phytoplankton increased around the entire Antarctic, although the reasons for this are still unclear (Smith and Comiso 2008);

coastal waters are a stronger biogenic $\mathrm{CO}_{2}$ sink than previously thought (Arrigo and others 2008a) - the productive Ross Sea shelf area accounts for $27 \%$ of the $\mathrm{CO}_{2}$ removed from the atmosphere by the entire Southern Ocean (Arrigo and others 2008b); 
The Polar Front shifted to the south, which has resulted in a turn-over of the pelagic system and shrinking of the Antarctic pelagic habitat by an area of $2.4 \%$ (Sokolov and Rintoul 2009);

the microbial community shifted towards smaller cells increasing the significance of the microbial loop for $\mathrm{CO}_{2}$ absorption in the sub-Antarctic (Evans and others 2011); emperor penguins in East Antarctica show low breeding success due to changes in the food-chain and seaice extent (Barbraud and others 2011a). Nevertheless, recent satellite surveys show that there are many more breeding colonies of emperor penguins than were previously known (Fretwell and others 2012).

56. Disintegration of parts of the Larsen ice shelf on the eastern side of the Antarctic Peninsula (Gutt and others 2011) caused several changes to the marine ecosystem:

phytoplankton blooms became a new carbon sink (Peck and others 2009a);

there was an invasion of pelagic keystone species and their predators (Scheidat and others 2011);

benthic systems responded at different speeds (Hauquier and others 2011);

a few typical shelf-inhabiting pioneer species have established successfully since the ice-shelf collapse and their populations are increasing;

deep-sea species associated with the previous nutrient-poor ecosystem can temporarily benefit from enhanced phytoplankton blooms;

areas with high rates of iceberg grounding were dominated by fast growing animals - icebergs can increase or decrease local primary production and change its composition (Schwarz and Schodlock 2009).

57. As $\mathrm{CO}_{2}$ dissolves in seawater the speciation of dissolved inorganic carbon is altered. This is a process termed ocean acidification. It potentially affects all marine organisms as it makes it more difficult for animals/plants to extract calcium carbonate $\left(\mathrm{CaCO}_{3}\right)$ from seawater to build skeletons and it influences other physiological processes. Availability of $\mathrm{CaCO}_{3}$ is also lower at low temperatures, and Antarctic marine species have recently been demonstrated to have smaller skeletons than those from lower latitudes (Watson and others 2012). Pelagic keystone species suffer from the effects of acidification, but a range extension of the calcium carbonate coccolithophore Emiliana huxleyi is associated with neither warming nor acidification (Cubillos and others 2007). Modern shells of the foraminiferan Globigerina bulloides weigh 30-35\% less than those preserved in Holocene-aged sediments, which is consistent with predicted effects of ocean acidification (Moy and others 2009). Few investigations have focused on abilities to compensate the negative effects or adapt to acidification, but a bivalve and a diatom are known to respond neutrally to acidification (Boelen and others 2011, Cummings and others 2011). Furthermore some echinoderms grow faster in lowered $\mathrm{pH}$ (DuPont and others 2010), and such capacities for Antarctic species are yet to be reported.

\section{Permafrost}

58. There is little information on recent changes in permafrost temperature in the Antarctic. On Signy Island the active layer (the permafrost layer experiencing seasonal freeze and thaw) increased in depth by $30 \mathrm{~cm}$ from 1963-1990, when the island was warming, then decreased by the same amount from 1990-2001, when it cooled slightly during the summer. In northern Victoria Land between 1996 and 2009 the active layer exhibited a thickening trend $(1 \mathrm{~cm}$ per year) comparable with the thickening rates observed in several Arctic locations. Over the same period (1999-2007) permafrost temperatures in northern Victoria Land showed an increase of $0.1^{\circ} \mathrm{C}$ per year at depths greater than $0.3 \mathrm{~m}$ down to 3.6 $\mathrm{m}$ despite the stability of the air temperature. On the other hand in McMurdo Sound the temperature history, reconstructed by the permafrost thermal profile from boreholes $30 \mathrm{~m}$ deep and using an inversion procedure, suggested a slight cooling from 1998 to 2003 followed by a slight warming to 2008. During the IPY period several other boreholes were drilled mainly in maritime Antarctica and in the coming years these data will provide a better estimate of permafrost and active layer responses to climate change.

\section{Tropospheric chemistry}

59. The elements cadmium (Cd), lead ( $\mathrm{Pd})$, bismuth (Bi), arsenic (As), and lithium (Li) are enriched across Antarctica relative to both ocean and upper crust elemental ratios. Global volcanic outgassing accounts for the majority of the Bi measured in East and West Antarctica and for a significant fraction of the $\mathrm{Cd}$ in East Antarctica. Nonetheless, global volcanic outgassing does not account for the enriched values of $\mathrm{Pb}$ or As. Local volcanic outgassing from Mount Erebus may account for a significant fraction of the As and Cd in West Antarctica and for a significant fraction in East Antarctic glaze/dune areas. Despite potential contributions from local and global volcanic sources, significant concentrations of $\mathrm{Pb}$, $\mathrm{Cd}$, and As remain across much of Antarctica, suggestive of increased influence of anthropogenic emissions (Dixon and others 2011b).

\section{The next 100 years}

60. Determining how the environment of the Antarctic will change over the next century has implications for policymakers and presents scientific challenges. The climate models used for assessing future climate change vary in complexity. Most of the current generation of climate models are climate 'simulators', in the sense that they attempt to represent, as realistically as is practical, known processes that are important in influencing climate change. They are the most realistic means we have currently of providing projections of future environmental behaviour, albeit crudely and at coarse resolution. The large regional climate variability around Antarctica makes it difficult to assess the skill of climate models in simulating recent change. However, there are clear biases 
in their representation of the mean state. Considering the implications of these biases for projections of $21 \mathrm{st}$ century change is an important aspect of assessing data from collections of climate models, which give a range of responses to anthropogenic forcing.

61. Numerically-based biological models cannot yet approach the relative sophistication of models of the physics of the climate system, while physical models do not approach the level of spatial scale or resolution required for application to biological systems, providing yet a further limitation on what can be said about biotic and ecosystem responses (Gutt and others 2012).

62. The degree to which the Earth's climate will change over the next century is dependent on the success of efforts to reduce greenhouse gas emissions. The 2009 ACCE report focused on outputs from IPCC models that assumed a doubling of $\mathrm{CO}_{2}$ and other gases by 2100 (the SRESA1B scenario). These outputs may be too conservative, given that some indicators are already changing faster than predicted in IPCC projections (Boden and others 2012). There are also uncertainties on climate carbon cycle feedbacks.

\section{Atmospheric circulation}

63. Coupled chemistry-climate models indicate that the recovery of the ozone hole will act to make the phase of the SAM more negative during the austral summer. However, general circulation models (GCMs) suggest that in other seasons increasing greenhouse gas concentrations are likely to act to continue strengthening the positive phase of the SAM resulting in stronger circumpolar westerly winds. There is still major uncertainty from models as to the relative size of changes in the SAM due to ozone-hole recovery and to increased greenhouse gases, which act in opposite senses on the SAM and with different seasonalities.

\section{Temperature}

64. The IPCC Fourth Assessment Report (AR4) models project significant surface warming over Antarctica to 2100 , by $0.34^{\circ} \mathrm{C}$ per decade over land and grounded ice sheets, within a range from 0.14 to $0.5^{\circ} \mathrm{C}$ per decade. Over land, the largest increase is projected for the highaltitude interior of East Antarctica. Despite this change, the surface temperature by the year 2100 will remain well below freezing over most of Antarctica and will not contribute to melting inland. Despite this, any increases in the number of 'degree days above freezing' in these continental inland locations, particularly at the 'microhabitat' scale relevant to the native terrestrial biota, will continue to exert a positive control on biological communities living there (Hodgson and others 2010).

65. Based on AR4, the largest atmospheric warming projected by the models is over the sea ice zone in winter $0.70 \pm 0.45^{\circ} \mathrm{C}$ per decade off East Antarctica), because of the retreat of the sea-ice edge and the consequent exposure of the ocean.

66. While there is confidence in the overall projection of warming, there remains low confidence in the regional detail, because of the large differences in regional outcomes between models.

67. The annual mean warming rate in the troposphere at $5 \mathrm{~km}$ above sea level is projected to be $0.28^{\circ} \mathrm{C}$ per decade - slightly smaller than the forecast surface warming.

68. As yet neither the magnitude nor frequency of changes to extreme conditions over Antarctica can be forecast - something that biologists need to assess potential impacts. The extreme temperature range between the coldest and warmest temperature of a given year is projected to decrease around the coasts and to show little change over the interior.

69. A global warming of $3^{\circ} \mathrm{C}$ is expected to cause larger temperature change in Antarctica (due to polar amplification mechanisms). A $4{ }^{\circ} \mathrm{C}$ warming in Antarctica within 100 years is abrupt compared to the past temperature variations documented in Antarctic ice cores (with the fastest change around $4^{\circ} \mathrm{C}$ per 1000 years during the last deglaciation). In Antarctica, local temperature changes corresponding to a global warming of $3^{\circ} \mathrm{C}$ reach temperature levels that were probably last encountered about 120 to 130,000 years BP, during the last interglacial period, albeit in response to a different perturbation (changes in insolation driven by changes in the Earth's orbit). The analogy between last interglacial and future changes is only partial due to different latitudinal and seasonal characteristics of orbital and greenhouse gas forcing, but many of the biological responses are expected to share similar trajectories.

70. The climate of the Antarctic is very variable on all timescales compared to lower latitude areas because of the non-linear interactions between the atmosphere, ocean and ice. This makes it difficult to separate natural climate variability from anthropogenic influences, such as an increase in greenhouse gas concentration. It also means that it is difficult to predict how the climate of the Antarctic and the Southern Ocean will change over the next few decades when the greenhouse gas concentration increases are relatively small compared to pre-industrial levels.

\section{Precipitation}

71. The current generation of numerical models underestimates precipitation across the Antarctic continent. This is due to problems in parameterising key processes that drive precipitation (for example because polar cloud microphysics is poorly understood), and because the smooth coastal escarpment in a coarse resolution model causes cyclones to precipitate less than they do in reality. Warmer air temperatures and associated higher atmospheric moisture in most models cause net precipitation to increase in the future. Most climate models simulate a precipitation increase over Antarctica in the coming century that is larger in winter than in summer. Model outputs suggest that the snowfall over the continent may increase by $20 \%$ compared to current values. With the expected southward movement of the mid-latitude storm track 
we can expect greater precipitation and accumulation in the Antarctic coastal region. The form that precipitation takes is of biological significance (liquid water is immediately available to biota whereas snow is not).

\section{The ozone hole}

72. By the middle of the 21 st century springtime concentrations of stratospheric ozone are expected to have significantly recovered and will have almost fully recovered by the end of the 21 st century. Models disagree about the timing of the recovery, but assuming future atmospheric dynamics are similar to today's, it has been forecast on empirical grounds that ozone loss rates will begin to decline noticeably between 2017 and 2021 (Hassler and others 2011). Increased greenhouse gas concentrations will have further cooled the stratosphere, which increases ozone in its global balance of chemical reactions, so ozone amounts outside the ozone hole period should then be greater than in the 1970s.

73. Greenhouse cooling in the upper mesosphere is offset by both radiative and dynamical feedbacks associated with $\mathrm{CO}_{2}$ (radiative transfer, solar heating in the 2 and $2.7 \mu \mathrm{m}$ IR bands and modification of mesospheric circulation) and the ozone depletion in recent decades. In the case of the latter, larger mesosphere/lower thermosphere region temperature changes may be expected over the next few decades as ozone levels recover.

\section{Tropospheric chemistry}

74. Various trace gases, such as dimethyl sulphide (DMS) generated by plankton, are released from the oceans and sea-ice (Asher and others 2011) around Antarctica. In a warmer world, with reduced sea ice extent, emissions of gases such as DMS would probably increase, with a wintertime minimum and an extended summer maximum. DMS is a source of cloud condensation nuclei (CCN) via its oxidation to sulphate. Increasing the number of $\mathrm{CCN}$ may increase cloudiness and albedo influencing the Earth's climate.

\section{Terrestrial biology}

75. Increased temperatures may promote growth and reproduction, but also locally cause drought and associated effects. Changes to water availability have a greater effect than temperature on microbial, vegetation and faunal dynamics. Future regional patterns of water availability are unclear, but climate models predict an increase in precipitation in coastal regions. An increase in the frequency and intensity of freeze-thaw events could readily exceed the tolerance limits of many endemic invertebrates. With increases in temperature, many terrestrial species may exhibit faster metabolic rates, shorter life cycles and local expansion of populations. Even subtle changes in temperature, precipitation and wind speed will probably alter the catchment of lakes, and of the time, depth and extent of their surface ice cover, water volume and chemistry, with resulting effects on lake and dependent terrestrial ecosystems. Warming also increases the likelihood of invasion by more competitive alien species carried by water and air currents, humans and other animals. Changes may alter the relative importance of different mechanisms and opportunity for dispersal and establishment of both native and exotic biota. Notably, current evidence suggests that humans may be responsible for two or more orders of magnitude of establishment events of non-indigenous species to Antarctica than would occur with natural colonisation processes (see discussion in Hughes and Convey 2012).

\section{The terrestrial cryosphere}

76. Existing ice-sheet models do not properly reproduce the observed behaviour of ice sheets, casting doubt on their predictive value. The models fail to take into account mechanical degradation (for example water causing cracks to propagate in summer), changing lubrication of the base of the ice by an evolving subglacial hydrological regime, or the influence of variable sub-ice-shelf melting on the flow of outlet glaciers and ice streams. Predictions of the future state of ice sheets are based on a combination of inferences from past behaviour, extension of current behaviour, and interpretation of proxy data and analogues from the geological record.

77. The most likely regions of future change are those that are changing most today. Warm CDW will continue to flow onto the continental shelf in the Amundsen Sea, melting the underside of the ice sheets and glaciers. If sea surface temperatures in the central tropical Pacific play a role in controlling the atmospheric forcing on the inflows, the future warming in that region predicted by coupled climate models would have the effect of strengthening the inflows. It has been suggested (Vaughan and Spouge 2002) that there is a $30 \%$ probability that loss of ice from the West Antarctic ice sheet could cause sea level to rise at a rate of $0.2 \mathrm{~cm}$ per year, and a $5 \%$ probability it could cause rates of $1 \mathrm{~cm}$ per year. In addition, the ice shelves in the Amundsen Sea Embayment could be entering a phase of collapse that could lead to de-glaciation of parts of the West Antarctic Ice Sheet. Ultimately, this sector could contribute $1.5 \mathrm{~m}$ to global sea level, so a contribution from this sector alone of some tens of centimetres by 2100 cannot be discounted. These estimates are based upon the assumption that the ice sheets will respond linearly to warming and that sea level contributions will be confined to the West Antarctic ice sheet. Evidence for past abrupt changes in climate and inclusion of all marine-based regions could significantly raise these estimates.

78. On the Antarctic Peninsula, most of the effects leading to loss of ice are confined to the northern part, which contains ice equating to a few centimetres of global sea-level rise. Increased warming will lead to southerly progression of ice shelf disintegrations along both coasts. These may be preceded by increases in surface and basal melting, and/or progressive retreat of the calving front. Prediction of the timing of ice shelf disintegration is not yet possible, but seems to relate to the progression of the $-9^{\circ} \mathrm{C}$ isotherm. Removal of ice shelves will cause 
glaciers to speed up as buttressing forces are reduced. The total volume of ice on the Peninsula is $59,158 \mathrm{~km}^{3}$, equivalent to $147 \pm 64 \mathrm{~mm}$ of sea-level or roughly one quarter of the sea-level contained within all glaciers and ice caps outside of the Greenland and Antarctic ice sheets. Increased warming is expected to lead to a substantial contribution to sea-level rise from the Peninsula. Radić and Hock (2011) have estimated the contribution to sea level rise by mass losses from the peripheral glaciers and ice caps from Antarctica at $21 \pm 12 \mathrm{~mm}$ sea level equivalent (mostly from the Antarctic Peninsula region) over the period 2001-2100.

\section{Sea level}

79. The IPCC's Fourth Assessment Report projected a range of global sea-level increase from 18 to $59 \mathrm{~cm}$ between 1980-1999 and 2090-2099. This did not include a contribution from the dynamically driven changes in flow for portions of either the Greenland or Antarctic ice sheets. Ice loss from Antarctica is expected to have major implications, particularly for northern hemisphere sea level. Regression modeling (Rahmstorf 2007; Vermeer and Rahmstorf 2009) suggests that by 2100 global sea level may rise by up to $1.94 \mathrm{~m}$ rather than the IPCC's suggested $59 \mathrm{~cm}$. Sea level will not rise uniformly, not least because of glacial isostatic adjustment, which makes areas freed of ice rise, and surrounding areas sink. The spatial pattern of sea-level rise projections shows a minimum in sea-level rise in the Southern Ocean and a maximum in the Arctic Ocean.

\section{Biogeochemistry}

80. Model projections for the remainder of the $21 \mathrm{st}$ century suggest that the Southern Ocean will be an increased sink of atmospheric $\mathrm{CO}_{2}$. The magnitude of the uptake will depend on how the ocean responds to increases in ocean warming and to stratification, which can drive both increases in $\mathrm{CO}_{2}$ uptake through biological and export changes, and decreases through solubility and density changes. Changes in atmospheric circulation (for example increases in the intensity of the southern hemisphere westerly winds associated with the SAM being in a positive phase) may affect the rate of deep ocean upwelling, bringing old $\mathrm{CO}_{2}$ to the surface and reducing the efficiency of the Southern Ocean $\mathrm{CO}_{2}$ sink.

\section{Marine biology}

81. Growth of phytoplankton is shaped by climate (Montes-Hugo and Yuan 2012) and determines the capacity of the Southern Ocean to act as a biological $\mathrm{CO}_{2}$ sink or source. Phytoplankton are exposed to changes in (a) sea ice, (b) nutrients, by upwelling or remineralisation, (c) micronutrients, for example by wind driven iron fertilisation, (d) stratification of the water column, (e) water characteristics: light, salinity, temperature, $\mathrm{CO}_{2}$, acidity, (f) habitat size and (g) biological interactions. Changes in primary production have already impacted and will continue to impact other marine organisms through provision of their primary food source. Metabolites derived from algae can accelerate climate change.

82. A theoretical Southern Ocean with only $5 \%$ of today's ice extent would produce $29 \%$ more algae due to the loss of sea ice as their habitat and an extension of pelagic zones (Arrigo and Thomas 2004). Ice is not the exclusive habitat for most small organisms, thus, their overall species richness will not be affected significantly. Penguin colonies north of $70^{\circ} \mathrm{S}$ are projected to decrease, but growth might occur to a limited extent south of $73^{\circ} \mathrm{S}$ (Ainley and others 2010). Negative effects would be evident in sea ice obligatory pack ice seals: crabeater, leopard, Ross (Siniff and others 2008), and ice-avoiding penguin species are likely to continue their southward expansion of range. Climate-induced potential effects of climate change on biogeographic ranges of selected mammals, including whales, were assessed by Learmonth and others (2006). Some icefish and pelagic fish species will also suffer from sea ice reduction since they depend on the ice shaping their habitat.

83. Model projections suggest warming of 0.5 to $0.75^{\circ} \mathrm{C}$ by 2100 of most surface and bottom waters, with exceptions in part of the more stable Weddell Sea (Hellmer and others 2012) and above average changes near the ACC (Sokolov and Rintoul 2009). Thus, the effects on the marine biota may be less than has been feared from laboratory experiments. Benthic organisms including fish are especially sensitive to warming. Most species have upper lethal temperatures below $10^{\circ} \mathrm{C}$. Some can survive only less than a $5^{\circ} \mathrm{C}$ change in combination with oxygen limitations (Peck and others 2009b). Performance of critical activities can be reduced long before lethal levels are reached. Species predicted on the basis of short-term experiments to suffer under only minor warming are found to be less impacted under longer term acclimatisation (Morley and others 2011), for example at $8^{\circ} \mathrm{C}$ above their usual temperature, such as the fish Pagothenia borchgrevinki (Franklin and Seebacher 2009). However, links between short-term temperature tolerance and prospects for surviving changing environments seem to exist (Barnes and others 2010). Several marine invertebrates are distributed across sites or depths with a greater temperature range than their 'typical Antarctic conditions', for example around South Georgia (Morley and others 2010). Nevertheless, it must be assumed that some of the already observed climate-induced impacts to the ecosystems will continue. Increasing intrusion of warmer water onto the shelf will result in a continued decline in habitat for crabeater seals, but elephant seals and possibly fur seals are likely to benefit regionally (Costa and others 2010). Genomic studies for example on the physiologically important nitrogen monoxide production and neuroglobin genes of icefish (Cheng and others 2009) may help to predict how icefish can cope with global change. Black-browed albatross and snow petrel populations are predicted to respond negatively to sea surface temperature warming and decline of sea ice (Barbraud and others 2011b). As mentioned earlier, 
a hypothesised spread of king crabs up onto the shelf within 1-2 decades (Smith and others 2012) could cause a complete ecological regime shift.

84. There are measurable changes in marine carbonate chemistry (ocean acidification) that have been shown to change physiological and biogeochemical systems. In the second half of this century the aragonite saturation horizon is likely to reach the ocean surface in parts of the Southern Ocean, making the entire water column undersaturated. The planktonic food chain, benthic life, remineralisation processes including the 'microbial loop' and the carbonate flux to the deep-sea (Hunt and others 2008) will all be significantly affected. Many groups including foraminifera, corals, molluscs (McClintock and others 2009), echinoderms (McClintock and others 2011), and coralline algae are potentially threatened unless they have mechanisms to prevent shell dissolution (see for example Fabry and others 2009). The observed transition from larger diatoms to smaller cryptophytes would result in a 40-65\% decrease of carbon supply to higher trophic levels, but to increased food supply to the benthos, from which suspension feeders might not benefit as much as the more opportunistic deposit feeders (for such benthic dynamics see Sumida and others 2008). The Southern Ocean is at higher risk than other oceans because it has low saturation levels of $\mathrm{CaCO}_{3}$ (Comeau and others 2012). Acidification is a serious threat because organisms cannot 'escape' if the entire ocean is affected.

85. Increasing $\mathrm{CO}_{2}$ can also lead to increased phytoplankton productivity, altered species composition and effects on biological carbon cycling creating climate feedbacks (Moreau and others 2012).

86. Direct and other disturbances that might occur include (Brandt and Gutt 2011; Somero 2012 and references therein):

increased ice scouring, leading to reduced benthic diversity in shallow depths;

increased scouring of large icebergs at greater depths leading to an increase of regional benthic biodiversity; long-term decreases in ice scour by icebergs, resulting in decreased biodiversity;

lack of anchor ice, preventing 'explosive' growth of opportunistic benthic species;

increased coastal sedimentation associated with deglaciation on land, smothering benthos and hindering feeding (Brey and others 2011);

freshening of surface waters changing buoyancy especially of eggs, and supporting the greater stratification of the water column with further impact on the food web and the response of the benthic system;

continuation of ice shelf disintegration, initiating major ecosystem regime shifts;

slight deoxygenation of surface waters, leading to more serious deoxygenation in deeper layers.

87. It seems unlikely that species will become extinct by 2100 due to warming, either because they are able to cope ecologically and physiologically with the predicted environmental changes, or because they are not restricted in their occurrence to an area with a harmful temperature increase (Brandt and Gutt 2011).

\section{Ocean circulation and water masses}

88. Ocean models have improved in recent years in resolution and in their representation of unresolved processes. Grid spacing as small as $10 \mathrm{~km}$ in the horizontal is not uncommon, yet even this relatively high resolution is not sufficient to resolve the smaller eddy structures at high latitudes. Small topographic features are crucial to resolve as well, for example for shelf-ocean exchange, and models are not able to capture this phenomenon very well. Given the key role of ocean eddies in north-south heat and property transport in the Southern Ocean, these limitations are important to overcome. Ocean models generally predict a very small net intensification of the ACC in response to the overall southward shift and intensification of the westerly winds over the Southern Ocean. However, there may be large regional differences in any meridional shift in the location of the ACC, with a northward change in the current cores possible in some locations. The increase in ACC transport projected for 2100 reaches a few Sverdrups $(1 \mathrm{~Sv}=$ one million cubic metres/second) in the Drake Passage, that is less than conventional techniques are able to measure. The enhanced winds induce a small southward displacement of the core of the ACC (less than $1^{\circ}$ in latitude on average). Model-based predictions of future ACC flow and structure are, however, currently inadequate.

89. The observed mid-depth and surface layer warming of the Southern Ocean is projected to continue (Sen Gupta and others 2009). Ocean ventilation could be increased because of enhanced divergence of surface waters induced by the increase in the wind stress and associated upwelling, however stronger stratification caused by heating and ice melt will counteract this and may suppress overturning circulation and ventilation, as per Helm and others (2011). The apparent contraction of the abyssal layer of AABW in the Southern Ocean has been attributed to the weakening of up to $-6.9 \mathrm{~Sv}$ in all the regional sources combined during the past few decades (Purkey and Johnson 2012), that is a dramatic slowdown of the lower limb of the global thermohaline circulation based solely on previous estimates of AABW production $(8.1 \mathrm{~Sv})$. Whether or not this contraction reflects changes in source strength or different modes of formations is not yet clear, hindering predictive skill concerning future patterns of abyssal warming. Model calculations suggest that bottom water formation will be reduced and deep water will slightly warm by 2100 (Sen Gupta and others 2009), though IPCC-class models do not represent Antarctic Bottom Water formation in anything approaching an acceptable way.

\section{Sea ice}

90. Since the current generation of coupled climate models have a very wide range of Southern Ocean sea ice climatologies with few simulating the increase in ice extent since the late 1970s (Turner and others 2013) we 
cannot have a high level of confidence in their predictions for the next century. However, the AR4 climate models suggest that the annual average total sea-ice area will decrease by $2.6\left(\times 10^{6} \mathrm{~km}^{2}\right.$, or $33 \%$ (Bracegirdle and others 2008). Most of the retreat is expected to be in winter and spring, so decreasing the amplitude of the seasonal cycle of sea ice area. The current generation of climate models is not able to provide a precise regional picture of the changes to be expected.

\section{Permafrost}

91. It is likely that there will be a degradation of permafrost conditions, accompanied by subsidence of ground surface, development of thermokarst, and triggering of mass movements. Active layer thickening is also predicted, although the link with air temperature is not so clear and other factors like snow cover and solar radiation significantly influence its evolution. Active layer thickening could have a significant impact on vegetation and soil ecosystems. Change is most likely in the northern Antarctic Peninsula and the South Shetland and South Orkney Islands and coastal areas in East Antarctica. The forecast changes imply risks to infrastructure and to ecosystems.

\section{Concluding remarks}

92. The climate of the high latitude areas is more variable than that of tropical or mid-latitude regions and has experienced a wide range of conditions over the last few million years. The snapshot we have of the climate during the instrumental period is limited in the long history of the continent, and separation of natural climate variability from anthropogenic influences is difficult. However, the effects of increased greenhouse gases and decreases in stratospheric ozone are already evident. The effects of the expected increase in greenhouses gases over the next century, if they continue to rise at the current rate, will be remarkable because of their speed, and because of polar amplification of the global warming signal. It should be borne in mind that equally rapid change was also typical in past deglaciations, for example 20,000 years ago at the end of the LGM. Removal of the surface cooling effect of the ozone hole as it diminishes in extent will accelerate the increase in surface temperature. We can make reasonably broad estimates of how quantities such as temperature, precipitation, acidification of the ocean and sea ice extent might change, and consider the possible impact on marine and terrestrial biota. We cannot yet say with confidence how the large ice sheets of Antarctica will respond, but observed recent rapid changes give cause for concern - especially for the stability of parts of West Antarctica.

\section{Acknowledgements}

We are grateful to Drs David Ainley, Lloyd Peck, David Thompson and Eric Wolff for valuable comments on a draft of this paper, and to Professor Andrew
Clarke and an anonymous reviewer for further helpful comments.

\section{References}

Abram, N.J., E.R. Thomas, J.R. McConnell, R. Mulvaney, T.J. Bracegirdle, L. C. Sime and A.J. Aristarain. 2010. Ice core evidence for a 20th century decline of sea ice in the Bellingshausen Sea, Antarctica. Journal of Geophysical ResearchAtmospheres 115: DOI: 10.1029/2010JD014644.

Agnew, D.J., T.R. Marlow, K. Lorenzen, J. Pompert, R.C. Wakeford and G.A. Tingley. 2003. Influence of Drake Passage oceanography on the parasitic infection of individual year-classes of southern blue whiting Micromesistius australis. Marine Ecology-Progress Series 254: $281-$ 291.

Ainley, D., J. Russell, S. Jenouvrier, E. Woehler, P. O. Lyver, W. R. Fraser and G.L. Kooyman. 2010. Antarctic penguin response to habitat change as Earth's troposphere reaches 2 degrees $\mathrm{C}$ above preindustrial levels. Ecological Monographs 80[1]: 49-66.

Allen, C.S., J. Pike, and C.J. Pudsey. 2011. Last glacialinterglacial sea-ice cover in the SW Atlantic and its potential role in global deglaciation. Quaternary Science Reviews 30(19-20): 2446-2458.

Arcone, S., R. Jacobel, and G.H. Hamilton. 2012. Unconformable stratigraphy in East Antarctica, Part 1: firn ultrasets and metamorphic growth, and model evidence for intensified accumulation. Journal of Glaciology in press.

Aronson, R.B., S. Thatje, J.B. McClintock, and K.A. Hughes. 2011. Anthropogenic impacts on marine ecosystems in Antarctica. Year in ecology and conservation biology. Annals of the New York Academy of Sciences 1223: 82-107.

Arrigo, K.R. and D.N. Thomas. 2004. Large-scale importance of sea ice biology in the Southern Ocean. Antarctic Science 16: 471-486. DOI:10.1017/S0954102004002263.

Arrigo, K.R., G. van Dijken and M. Long. 2008a. Coastal Southern Ocean: a strong anthropogenic $\mathrm{CO}_{2}$ sink. Geophysical Research Letters 35(21): DOI: 10.1029/2008GL035624.

Arrigo, K.R., G.L. van Dijken and S. Bushinsky. 2008b. Primary production in the Southern Ocean, 1997-2006. Journal of Geophysical Research-Oceans 113(C8): DOI:10.1029/ 2007JC004551.

Asher, E.C., J.W.H. Dacey, M.M. Mills, K.R. Arrigo and P.D. Tortell. 2011. High concentrations and turnover rates of DMS, DMSP and DMSO in Antarctic sea ice. Geophysical Research Letters 38: DOI: 10.1029/2011GL049712.

Ballare, C.L., M.M. Caldwell, S.D. Flint, S.A. Robinson and J.F. Bornman. 2011. Effects of solar ultraviolet radiation on terrestrial ecosystems. Patterns, mechanisms, and interactions with climate change. Photochemical and Photobiological Sciences 10: 226-241.

Barbraud, C., M. Gavrilo, Y. Mizin and H. Weimerskirch. 2011a. Comparison of emperor penguin declines between Pointe Geologie and Haswell Island over the past 50 years. Antarctic Sciences 23(5): 461-468.

Barbraud, C., P. Rivalan, P. Inchausti, M. Nevoux, V. Rolland, and H. Weimerskirch. 2011b:. Contrasted demographic responses facing future climate change in Southern Ocean seabirds. Journal of Animal Ecology 80[1]: 89-100.

Barnes, D.K.A. and C.D. Hillenbrand. 2010. Faunal evidence for a late quaternary trans-Antarctic seaway. Global Change Biology 16(12): 3297-3303.

Barnes, D.K.A., L.S. Peck and S.A. Morley. 2010. Ecological relevance of laboratory determined temperature limits: colonization potential, biogeography and resilience of Antarctic 
invertebrates to environmental change. Global Change Biology 16(11): 3164-3169.

Barnes, D.K.A. and T. Souster. 2011. Reduced survival of Antarctic benthos linked to climate-induced iceberg scouring. Nature Climate Change 1(7): 365-368.

Beers, J.M. and B.D. Sidell. 2011. Thermal tolerance of Antarctic notothenioid fishes correlates with level of circulating hemoglobin. Physiological and Biochemical Zoology 84(4): 353362.

Beig, G., J. Scheer, M.G. Mlynczak and P. Keckhut. 2008. Overview of the temperature response in the mesosphere and lower thermosphere to solar activity. Reviews of Geophysics 46: DOI: 10.1029/2007RG000236.

Bertler, N.A.N., P.A. Mayewski and L. Carter. 2011. Cold conditions in Antarctica during the Little Ice Age - implications for abrupt climate change mechanisms. Earth and Planetary Science Letters 308(1-2): 41-51.

Blunden, J. and D.S. Arndt. 2012. State of the climate in 2011. Bulletin of the American Meteorological Society 93: S1S282.

Boden, T.A., G. Marland and R.J. Andres. 2012. Global, regional, and national fossil-fuel $\mathrm{CO}_{2}$ emissions. Oak Ridge, Tenn: US Department of Energy, Carbon Dioxide Information Analysis Center. DOI: 10.3334/CDIAC/00001_V2012.

Boelen, P., W.H. Van De Poll, H.J. Van Der Strate, I.A. Neven, J. Beardall, and A.G.J. Buma. 2011. Neither elevated nor reduced $\mathrm{CO}_{2}$ affects the photo-physiological performance of the marine Antarctic diatom Chaetoceros brevis. Journal of Experimental Marine Biology and Ecology 406: $38 \mathrm{e} 45$.

Böning, C.W., A. Dispert, M. Visbeck, S.R. Rintoul and F.U. Schwarzkopf. 2008. The response of the Antarctic Circumpolar Current to recent climate change. Nature Geoscience 1(12): 864-869.

Bracegirdle, T.J., W.M. Connolley and J. Turner. 2008. Antarctic climate change over the twenty first century. Journal of Geophysical Research 113: D03103: DOI:10.1029/ 2007JD008933.

Brandt, A. and J. Gutt. 2011. Biodiversity of a unique environment: the Southern Ocean benthos shaped and threatened by climate change. In: Zachos, F.E. and J.C. Habel (editors). Biodiversity hotspots. Berlin: Springer: 503-526.

Brey, T., M. Voigt, K. Jenkins and I.Y. Ahn. 2011. The bivalve Laternula elliptica at King George Island - A biological recorder of climate forcing in the West Antarctic Peninsula region. Journal of Marine Systems 88(4): 542-552.

Bromwich, D.H., J.P. Nicolas, A.J. Monaghan, M.A. Lazzara, L.M. Keller, G.A. Weidner and A.B. Wilson. 2013. Central West Antarctica among the most rapidly warming regions on Earth. Nature Geoscience 6: 139-145.

Burke, A. and L.F. Robinson. 2012. The Southern Ocean's role in carbon exchange during the last deglaciation. Science 335: 557-561.

Cheng, C.H.C., G. di Prisco and C. Verde. 2009. Cold-adapted Antarctic fish: the discovery of neuroglobin in the dominant suborder Notothenioidei. Gene 433(1-2): 100-101.

Clarke, L.J., S.A. Robinson, Q. Hua, D.J. Ayre and D. Fink. 2012. Radiocarbon bomb spike reveals biological effects of Antarctic climate change. Global Change Biology 18: 301310: DOI:10.1111/j.1365-2486.2011.02560.

Collins, L.G., J. Pike, C.S. Allen and D. A. Hodgson. in press. High resolution reconstruction of Southwest Atlantic sea-ice and its role in the climate changes of marine isotope stages 3 and 2. Paleoceanography : DOI: 10.1029/2011PA002264.

Comeau, S., J.P. Gattuso, A.M. Nisumaa and J. Orr. 2012. Impact of aragonite saturation state changes on migratory pteropods. Proceedings of the Royal Society B-Biological Sciences 279(1729): 732-738.

Comiso, J.C., R. Kwok, S. Martin and A.L. Gordon. 2011. Variability and trends in sea ice extent and ice production in the Ross Sea, Journal of Geophysical Research 116: doi:10.1029/2010JC006391.

Convey, P., R. Bindschadler, G. di Prisco, E. Fahrbach, J. Gutt, D.A. Hodgson, P.A. Mayewski, C.P. Summerhayes, J. Turner and The ACCE Consortium. 2009. Review: Antarctic climate change and the environment. Antarctic Science 21: 541-563.

Cook, A.J. and D.G. Vaughan. 2010. Overview of areal changes of the ice shelves on the Antarctic Peninsula over the past 50 years. The Cryosphere 4: 77-98.

Cook, A.J., S. Poncet, A.P.R. Cooper, D.J. Herbert and D. Christie. 2010. Glacier retreat on South Georgia and implications for the spread of rats. Antarctic Science 22: 255-263.

Costa, D.P., L.A. Huckstadt, D.E. Crocker, B.I. McDonald, M.E. Goebel and M.A. Fedak. 2010. Approaches to studying climate change and its role on the habitat selection of Antarctic pinnipeds. Integrative and Comparative Biology (doi:10.1093/icb/icq054).

Cubillos, J.C., S.W. Wright, G. Nash, M.F. de Salas, B. Griffiths, B. Tilbrook, A. Poisson and G.M. Hallegraeff. 2007. Calcification morphotypes of the coccolithophorid Emiliania huxleyi in the Southern Ocean: changes in 2001 to 2006 compared to historical data. Marine Ecology-Progress Series 348: 47-54.

Cummings, V., J. Hewitt, A. Van Rooyen, K. Currie, S. Beard, S. Thrush, J. Norkko, N. Barr, P. Heath, N.J. Halliday, R. Sedcole, A. Gomez, C. McGraw and V. Metcalf. 2011. Ocean acidification at high latitudes: potential effects on functioning of the Antarctic bivalve Laternula elliptica. PLOS ONE 6(1): e16069 (doi: 10.1371/journal.pone.0016069).

Davies, B.J., J.L. Carrivick, N.F. Glasser, M.J. Hambrey and J.L. Smellie. 2012. Variable glacier response to atmospheric warming, Northern Antarctic Peninsula. The Cryosphere 6: 1031-1048.

De Wever, A., F. Leliaert, E. Verleyen, P. Vanormelingen, K. Van der Gucht, D.A. Hodgson, K. Sabbe, and W. Vyverman. 2009. Hidden levels of phylodiversity in Antarctic green algae: further evidence for the existence of glacial refugia. Proceedings of the Royal Society B-Biological Sciences 276(1673): 35913599.

Ding, Q., E.J. Steig, D.S. Battisti and M. Kuttel. 2011. Winter warming in West Antarctica caused by central tropical Pacific warming. Nature Geoscience 4: 398-403.

Dixon, D.A., P.A. Mayewski, I.D. Goodwin, G.J. Marshall, R. Freeman, K.A. Maasch and S.B. Sneed. 2012. An ice-core proxy for northerly air mass incursions into West Antarctica. International Journal of Climatology 32: 1455-1465.

Dixon, D.A., P.A. Mayewski, E. Korotkikh, S.B. Sneed, M.J. Handley, D.S. Introne and T. Scambos. 2011b. A spatial framework for assessing current conditions and monitoring future change in the chemistry of the Antarctic atmosphere. The Cryosphere 5: 885-950.

Doran, P.T., J.C. Priscu, W.B. Lyons, J.E. Walsh, A.G. Fountain, D.M. McKnight, D.L. Moorhead, R.A. Virginia, D.H. Wall, G.D. Clow, C.H. Fritsen, C.P. McKay and A.N. Parsons. 2002. Antarctic climate cooling and terrestrial ecosystem response. Nature 415: 517-520.

Dupont, S., B. Lundve and M. Thorndyke. 2010. Near future ocean acidification increases growth rate of the lecithotrophic larvae and juveniles of the sea star Crossaster papposus. Journal of Experimental Zoology Part B Molecular and Developmental Evolution. 314(5): 382-389.

Ekaykin, A.A., Yu.A. Shibaev, V.Ya. Lipenkov, A.N. Salamatin and S.V. Popov. 2011. Glaciological and geophysical 
investigations along the ice flow-lines passing through the subglacial lake Vostok (in Russian). In: Kotlyakov, V. M. (editor). Contribution of Russia to International Polar Year 2007/2008. Polar Cryosphere and Continental Waters. Moscow: Paulsen: 48-69.

Evans, C., P.G. Thomson, A.T. Davidson, A.R. Bowie, R. van den Enden, H. Witte and C.P.D. Brussaard. 2011. Potential climate change impacts on microbial distribution and carbon cycling in the Australian Southern Ocean. Deep-Sea Research Part II-Topical Studies in Oceanography 58(21-22): 2150-2161.

Fabry, V.J., J.B. McClintock, J.T. Mathis and J.M. Grebmeier. 2009. Ocean acidification at high latitudes: the bellweather. Oceanography 22(4): 160-171.

Fogt, R.L. and D.H. Bromwich. 2006 Decadal variability of the ENSO teleconnection to the high latitude South Pacific governed by coupling with the Southern Annular Mode. Journal of Climate 19: 979-997.

Fogt, R.L., J. Perlwitz, A.J. Monaghan, D.H. Bromwich, J.M. Jones and G.J. Marshall. 2009. Historical SAM variability 2009. Part II: Twentieth-century variability and trends from reconstructions, observations, and the IPCC AR4 models. Journal of Climate 22: 5346-5365.

Franklin, C.E. and F. Seebacher. 2009. Adapting to climate change. Science 323(5916): 876.

French, W.J.R. and A.R. Klekociuk. 2011. Long-term trends in Antarctic winter hydroxyl temperatures, Journal of Geophysical Research 116 D00P09:DOI :10.1029/2011JD015731.

Fretwell, P.T., M.A. LaRue, P. Morin, G.L. Kooyman, B. Wienecke, N. Ratcliffe, A.J. Fox, A.H. Fleming, C. Porter, and P.N. Trathan. 2012. An emperor penguin population estimate: the first global, synoptic survey of a species from space. PLOS ONE 7(4): e33751 DOI:10.1371/journal.pone.0033751.

Gille, S.T. Warming of the Southern Ocean since the 1950s. 2002. Science 295: 1275-1277.

Goosse, H., M. Braida, X. Crosta, A. Mairesse, V. MassonDelmotte, P. Mathiot, R. Neukom, H. Oeter, G. Philippon, H. Renssen, B. Stenni, T. van Ommen and E. Verleyen. 2012. Antarctic temperature changes during the last millennium: evaluation of simulations and reconstructions. Quaternary Science Reviews 55: 75-90.

Graham, R.M., A.M. de Boer, B. Bolin, K.J. Heywood, M.R. Chapman and D.P. Stevens. 2012. Southern Ocean fronts: controlled by wind or topography? Journal of Geophysical Research 117 :DOI :10.1029/2012JC007887.

Gutt, J., I. Barratt, E. Domack, C.D. d'Acoz, W. Dimmler, A. Gremare, O. Heilmayer, E. Isla, D. Janussen, E. Jorgensen, K.H. Kock, L.S. Lehnert, P. Lopez-Gonzales, S. Langner, K. Linse, M.E. Manjon-Cabeza, M. Meissner, A. Montiel, M. Raes, H. Robert, A. Rose, E.S. Schepisi, T. Saucede, M. Scheidat, H.W. Schenke, J. Seiler and C. Smith. 2011. Biodiversity change after climate-induced ice-shelf collapse in the Antarctic. Deep-Sea Research Part li-Topical Studies in Oceanography 58(1-2): 74-83.

Gutt, J., G. Hosie and M. Stoddard. 2010. Life in the world's oceans: diversity, distribution, and abundance. In: Mclntyre, A.D. (editor). Marine life in the Antarctic. Oxford: WileyBlackwell : 203-220.

Gutt, J., D. Zurell, T.J. Bracegirdle, W. Cheung, M.S. Clark, P. Convey, B. Danis, B. David, C. De Broyer, G. di Prisco, H. Griffiths, R. Laffont, L.S. Peck, B. Pierrat, M.J. Riddle, T. Saucede, J. Turner, C. Verde, Z. Wang and V. Grimm. 2012. The use of correlative and dynamic species distribution modelling for ecological predictions in the Antarctic: a cross-disciplinary concept. Polar Research 31 : (doi.org/10.3402/polar.v31i0.11091).
Hassler, B., J.S. Daniel, B.J. Johnson, S. Solomon, and S.J. Oltmans. 2011. An assessment of changing ozone loss rates at South Pole: twenty-five years of ozonesonde measurements. Journal of Geophysical Research-Atmospheres 116: DOI: 10.1029/2011JD016353.

Hauquier, F., J. Ingels, J. Gutt, M. Raes and A. Vanreusel. 2011. Characterisation of the Nematode community of a lowactivity cold seep in the recently ice-shelf free Larsen B area, eastern Antarctic Peninsula. Plos One 6(7) e22240: DOI : 10.1371/journal.pone.0022240.

Hellmer, H.H., F. Kauker, R. Timmermann, J. Determann and J. Rae. 2012. Twenty-first-century warming of a large Antarctic ice-shelf cavity by a redirected coastal current. Nature 485: 225-228.

Hellmer, H.H., O. Huhn, D. Gomis and T. Timmermann. 2011. On the freshening of the northwestern Weddell Sea continental shelf, Ocean Science 7: 305-316: DOI:10.5194/os-7-3052011.

Helm, K.P., N.L. Bindoff and J.A. Church. 2011. Observed decreases in oxygen content of the global ocean. Geophysical Research Letters 38: L23602: DOI:10.1029/2011GL049513.

Hodgson, D.A. 2011. First synchronous retreat of ice shelves marks a new phase of polar deglaciation. Proceedings of the National Academy of Sciences of the United States of America 108(47): 18859-18860.

Hodgson, D.A., P. Convey, E. Verleyen, W. Vyverman, W. Mclntosh, C.J. Sands, R. Fernandez-Carazo, A. Wilmotte, A. DeWever, K. Peeters, I. Tavernier and A. Willems. 2010. The limnology and biology of the Dufek Massif, Transantarctic Mountains $82^{\circ}$ south. Polar Science 4: 197-214.

Hodgson, D. A., D. Roberts, A. McMinn, E. Verleyen, B. Terry, C. Corbett and W. Vyverman. 2006. Recent rapid salinity rise in three East Antarctic lakes. Journal of Paleolimnology 36(4): 385-406.

Hogg, A.M., M.P. Meredith, J.R. Blundell and C. Wilson. 2008. Eddy heat flux in the Southern Ocean: response to variable wind forcing. Journal of Climate 21: 608-620.

Holland, P.R. and R. Kwok. 2012. Wind-driven trends in Antarctic sea-ice drift. Nature Geoscience 5: 872-875.

Hughes, K.A. and P. Convey. 2012. Determining the native/nonnative status of newly discovered terrestrial and freshwater species in Antarctica - current knowledge, methodology and management action. Journal of Environmental Management 93 (1): 52-66.

Hunt, B.P.V., E.A. Pakhomov, G.W. Hosie, V. Siegel, P. Ward and K. Bernard. 2008. Pteropods in Southern Ocean ecosystems. Progress in Oceanography 78(3): 193-221.

Jacobs, S. S., C.F. Giulivi and P.A. Mele. 2002. Freshening of the Ross Sea during the late 20th Century. Science 297: 386389.

Jacobs, S.S., A. Jenkins, C.F. Giulivi and P. Dutrieux. 2011. Stronger ocean circulation and increased melting under Pine Island Glacier ice shelf. Nature Geoscience 4(8): 519-523.

Jenkins, A., P. Dutrieux, S.S. Jacobs, S.D. McPhail, J.R. Perrett, A.T. Webb and D. White. 2010. Observations beneath Pine Island Glacier in West Antarctica and implications for its retreat. Nature Geoscience 3(7): 468-472.

Kopp, R.E., F.J. Simons, J.X. Mitrovica, A.C. Maloof and M. Oppenheimer. 2009. Probabilistic assessment of sea level during the last interglacial stage. Nature 462(7275): 863867.

Korhonen, H., K.S. Carslaw, P.M. Forster, S. Mikkonen, N.D. Gordon and H. Kokkola. 2010. Aerosol climate feedback due to decadal increases in Southern Hemisphere wind speeds. Geophysical Research Letters 37: DOI:10.1029/2009GL041320. 
Kozachek, A.V., A. A. Ekaykin, V. Ya. Lipenkov, Yu. A. Shibaev, and $R$. Vaikmäe. 2011. On the relationship between climatic variability in central Antarctica and the climate of middle and low latitudes of Southern Hemisphere [in Russian]. Problems of Arctic and Antarctic 90 (4): 5-13.

Lachlan-Cope, T. A., W.M. Connolley, J. Turner, H.K. Roscoe, G.J. Marshall, S.R. Colwell, M. Höpfner and W.J. Ingram. 2009. Antarctic winter tropospheric warming - the potential role of polar stratospheric clouds, a sensitivity study. Atmospheric Science Letters 10: 262-266.

Learmonth, J.A., C.D. MacLeod, M.B. Santos, G.J. Pierce, H.Q.P. Crick and R.A. Robinson. 2006. Potential effects of climate change on marine mammals. Oceanography and Marine Biology - An Annual Review 44: 431-464.

Le Quéré, C., C. Rödenbeck, E.T. Buitenhuis, T. J. Conway, R. Langenfelds, A. Gomez, C. Labuschagne, M. Ramonet, T. Nakazawa, N. Metzl, N.P. Gillet and M. Heimann. 2007. Saturation of the Southern Ocean $\mathrm{CO}_{2}$ sink due to climate change. Science 316: 1735-1738.

Liu, J.P. and J.A. Curry. 2010. Accelerated warming of the Southern Ocean and its impacts on the hydrological cycle and sea ice. Proceedings of the National Academy of Sciences of the United States of America 107(34): 14987-14992.

Martinson, D.G., S.E. Stammerjohn, R.A. Iannuzzi, R.C. Smith and M. Vernet. 2008. Western Antarctic Peninsula physical oceanography and spatio-temporal variability. Deep-Sea Research 55(18-19): 1964-1987.

Matschiner, M., R. Hanel and W. Salzburger. 2011. On the origin and trigger of the notothenioid adaptive radiation. Plos One 6(4). e18911: DOI:10.1371/journal.pone.0018911.

Marshall, G.J., A. Orr, N.P.M. van Lipzig and J.C. King. 2006. The impact of a changing Southern Hemisphere annular mode on Antarctic Peninsula summer temperatures. Journal of Climate 19(20): 5388-5404.

Mayewski, P.A., E.E. Rohling, J.C. Stager, W. Karlen, K.A. Maasch, L.D. Meeker, E.A. Meyerson, F. Gasse, S. van Kreveld, K. Holmgren, J. Lee-Thorp, G. Rosqvist, F. Rack, M. Staubwasser, R.R. Schneider and E. J. Steig. 2004. Holocene climate variability. Quaternary Research 62: 243255.

Mayewski, P.A., M.P. Meredith, C.P. Summerhayes, J. Turner, A.P. Worby, P.J. Barrett, G. Casassa, N.A.N. Bertler, T.J. Bracegirdle, A.C. Naveira-Garabato, D. H. Bromwich, H. Campbell, G.H. Hamilton, W.B. Lyons, K.A. Maasch, S. Aoki and C. Xiao. 2009. State of the Antarctic and Southern Ocean climate system (SASOCS). Reviews of Geophysics 47, RG1003: DOI:10.1029/2007RG000231.

Mayewski, P.A., K.A. Maasch, Y. Yan, S. Kang, E. Meyerson, S.B. Sneed, S. Kaspari, D. Dixon, V. Morgan, T. van Ommen and M. A. J. Curran. 2006. Solar forcing of the polar atmosphere. Annals of Glaciology 41: 147-154.

McClintock, J., H. Ducklow and W. Fraser. 2008. Ecological responses to climate change on the Antarctic Peninsula. American Scientist 96(4): 302-310.

McClintock, J., R.A. Angus, M.R. Mcdonald, C.D. Amsler, S.A Catledge, and Y.K. Vohra. 2009. Rapid dissolution of shells of weakly calcified Antarctic benthic macroorganisms indicates high vulnerability to ocean acidification. Antarctic Science 21: 449-456.

McClintock, J.B., M.O. Amsler, R.A. Angus, R.C. Challener, J.B. Schram, C.D. Amsler, C.L. Mah, J. Cuce and B.J. Baker. 2011. The Mg-Calcite composition of Antarctic echinoderms: important implications for predicting the impacts of ocean acidification. Journal of Geology 119(5): 457-466.

McGaughran, A., Torricelli G., Carapelli A., Frati F., Stevens M.I., Convey P. and Hogg I.D. 2010. Contrasting phylogeo- graphical patterns for springtails reflect different evolutionary histories between the Antarctic Peninsula and continental Antarctica. Journal of Biogeography 37: 103-119.

Mclntyre, T., I.J. Ansorge, H. Bornemann, J. Plotz, C.A. Tosh and M.N. Bester. 2011. Elephant seal dive behaviour is influenced by ocean temperature: implications for climate change impacts on an ocean predator. Marine EcologyProgress Series 441: 257-272.

Meredith, M.P., A.C.N. Garabato, A. M. Hogg and R. Farneti. 2012. Sensitivity of the overturning circulation in the Southern Ocean to decadal changes in wind forcing. Journal of Climate 25(1): 99-110.

Meredith, M.P. and A.M. Hogg. 2006. Circumpolar response of Southern Ocean eddy activity to a change in the Southern Annular Mode. Geophysical Research Letters 33: L16608 : DOI:10.1029/2006GL026499.

Meredith, M.P. and J.C. King. 2005. Climate change in the ocean to the west of the Antarctic Peninsula during the second half of the 20th century. Geophysical Research Letters. 32: L19606 : DOI:10.1029/2005GL024042.

Meredith, M.P., P.L. Woodworth, T.K. Chereskin, D.P. Marshall, L.C. Allison, G.R. Bigg, K. Donohue, K.J. Heywood, C.W. Hughes, A. Hibbert, A. McC. Hogg, H.L. Johnson, L. Jullion, B.A. King, H. Leach, Y.-D. Lenn, M.A. Morales Maqueda, D.R. Munday, A.C. Naveira Garabato, C. Provost, J.-B. Sallee and J. Sprintall. 2011. Sustained monitoring of the Southern Ocean at Drake Passage: past achievements and future priorities Reviews of Geophysics, 49: RG4005 : DOI:10.1029/2010RG000348.

Meyerson, E. A., P.A. Mayewski, S.I. Whitlow, L.D. Meeker, K.J. Kreutz and M.S. Twickler. 2002. The extratropical expression of ENSO recorded in a South Pole glaciochemical time series. Annals of Glaciology 35: 430-436.

Monaghan, A.J., D.H. Bromwich, R.L. Fogt, S.-H. Wang, P.A. Mayewski, D.A. Dixon, A. Ekaykin, M. Frezzotti, I. Goodwin, E. Isaksson, S.D. Kaspari, V.I. Morgan, H. Oerter, T.D. van Ommen, C.J. van der Veen and J. Wen. 2006. Insignificant change in Antarctic snowfall since the International Geophysical Year. Science 313: 827-831.

Montes-Hugo, M.A. and X. Yuan. 2012. Climate patterns and phytoplankton dynamics in Antarctic latent heat polynyas. Journal of Geophysical Research.: DOI:10.1029/ 2010JC006597.

Montes-Hugo, M., S.C. Doney, H.W. Ducklow, W. Fraser, D. Martinson, S.E. Stammerjohn and O. Schofield. 2009. Recent changes in phytoplankton communities associated with rapid regional climate change along the western Antarctic Peninsula. Science 323(5920): 1470-1473.

Moreau, S., I.R. Schloss, B. Mostajir, S. Demers, G.O. Almandoz, M.E. Ferrario and G.A. Ferreyra. 2012. Influence of microbial community composition and metabolism on air-sea $\Delta \mathrm{pCO}_{2}$ variation off the western Antarctic Peninsula. Marine Ecology Progress Series 446: 45-59.

Morley, S.A., H.J. Griffiths, D.K.A. Barnes and L.S. Peck. 2010. South Georgia: a key location for linking physiological capacity to distributional changes in response to climate change. Antarctic Science 22(6): 774-781.

Morley, S.A., V. Lemmon, B.E. Obermuller, J.I. Spicer, M.S. Clark and L.S. Peck. 2011. Duration tenacity: a method for assessing acclimatory capacity of the Antarctic limpet, Nacella concinna. Journal of Experimental Marine Biology and Ecology 399(1): 39-42.

Moy, A.D., W.R. Howard, S.G. Bray and T.W. Trull. 2009. Reduced calcification in modern Southern Ocean planktonic foraminifera. Nature Geoscience 2(4): 276280. 
Mulvaney, R., N.J. Abram, R.C.A. Hindmarsh, C. Arrowsmith, L. Fleet, J. Triest, L.C. Sime, O. Alemany, S. Foord. 2012. Recent Antarctic Peninsula warming relative to Holocene climate and ice-shelf history. Nature 489:141-144.

Muto, A., T.A. Scambos, K. Steffen, A.G. Slater, and G.D. Clow. 2011. Recent surface temperature trends in the interior of East Antarctica from borehole firn temperature measurements and geophysical inverse methods. Geophysical Research Letters, 38: L15502: DOI:10.1029/2011GL048086.

Newsham, K.K. and S.A. Robinson. 2009. Responses of plants in polar regions to UV-B exposure: a meta-analysis. Global Change Biology 15: 2574-2589.

Nielsen, U.N., D.H. Wall, J.A. Byron and A.V. Ross. 2011. Antarctic nematode communities: observed and predicted responses to climate change. Polar Biology : DOI 10.1007/s00300-011-1021-2.

Nowacek, D.P., A.S. Friedlaender, P.N. Halpin, E.L. Hazen, D.W. Johnston, A.J. Read, B. Espinasse, M. Zhou and Y.W. Zhu. 2011. Super-aggregations of krill and humpback whales in Wilhelmina Bay, Antarctic Peninsula. Plos One 6(4) (DOI: 10.1371/journal.pone.0019173).

O'Donnell, R., N. Lewis, S. Mclntyre and J. Condon. 2011. Improved methods for PCA-based reconstructions: case study using the Steig et al. (2009) Antarctic temperature reconstruction. Journal of Climate 24(8): 2099-2115.

Orsi, A.J., B.D. Cornuelle and J.P. Severinghaus. 2012. Little Ice Age cold interval in West Antarctica: evidence from borehole temperature at the West Antarctic Ice Sheet (WAIS) divide, Geophysical Research Letters 39: L09710 DOI:10.1029/2012GL051260).

Pagani, M., M. Huber, Z.H. Liu, S.M. Bohaty, J. Henderiks, W. Sijp, S. Krishnan and R.M. DeConto. 2011. The role of carbon dioxide during the onset of Antarctic glaciation. Science 334(6060): 1261-1264.

Peck, L.S., D.K.A. Barnes, A.J. Cook, A.H. Fleming and A. Clarke. 2009a. Negative feedback in the cold: ice retreat produces new carbon sinks in Antarctica. Global Change Biology (DOI: 10.1111/j.1365-2486.2009.02071).

Peck, L.S., S. Morley and M. S. Clark. 2009b. Animal temperature limits and ecological relevance: effects of size, activity and rates of change. Comparative Biochemistry and Physiology A-Molecular and Integrative Physiology 153A: S57S57.

Peeters, K., E. Verleyen, D. A. Hodgson, P. Convey, D. Ertz, W. Vyverman and A. Willems. 2011. Heterotrophic bacterial diversity in aquatic microbial mat communities from Antarctica. Polar Biology : DOI 10.1007/s00300-00011-01100-00304.

Pike, J., G.E.A. Swann, M.J. Leng and A.M. Snelling. 2013. Glacial discharge along the west Antarctic Peninsula during the Holocene, Nature Geoscience : DOI:10.1038/ ngeo1703).

Pollard, D. and R.M. DeConto. 2009. Modelling West Antarctic ice sheet growth and collapse through the past five million years. Nature 458(7236): 329-332 (doi: 10.1038/nature07809).

Pritchard, H.D., S.R.M. Ligtenberg, H.A. Fricker, D.G. Vaughan, M. R. van den Broeke and L. Padman. 2012. Antarctic icesheet loss driven by basal melting of ice shelves. Nature 502 (doi:10.1038/nature10968).

Purkey, S. and G. Johnson. 2010. Warming of global abyssal and deep southern ocean waters between the 1990s and 2000s: contributions to global heat and sea level rise budgets. Journal of Climate 23: 6336-6351.

Purkey, S.G., and G.C. Johnson. 2012. Global contraction of Antarctic Bottom Water between the 1980s and 2000s. Journal of Climate, 25: 5830-5844 (doi:10.1175/JCLI-D-1100612.1).
Radić, V. and R. Hock. 2011. Regionally differentiated contribution of mountain glaciers and ice caps to future sea-level rise. Nature Geoscience. 4(2): 91-94.

Rahmstorf, S. 2007. A semi-empirical approach to projecting future sea-level rise. Science 315(5810): 368-370.

Rau, F., F. Mauz, H. De Angelis, R. Jana, J.A. Neto, P. Skvarca, S. Vogt, H. Saurer and H. Gossmann. 2004. Variations of glacier frontal positions on the northern Antarctic Peninsula. Annals of Glaciology 39: 525-530.

Rintoul, S.R. 2007. Rapid freshening of Antarctic Bottom Water formed in the Indian and Pacific oceans. Geophysical Research Letters 34(6): DOI: 10.1029/2006GL028550.

Rose, N.L., V.J. Jones, P.E. Noon, D.A. Hodgson, R.J. Flower and P.G. Appleby. 2012. Long-range transport of pollutants to the Falkland Islands and Antarctica: evidence from lake sediment fly-ash particle records. Journal of Environmental Science and Technology 46: 9881-9889.

Ruckamp, M., M. Braun, S. Suckro and N. Blindow. 2011. Observed glacial changes on the King George Island ice cap, Antarctica, in the last decade. Global Planetary Change 79(1-2): 99-109.

Scambos, T.A., C. Hulbe, M. Fahnestock and J. Bohlander. 2000. The link between climate warming and breakup of ice shelves in the Antarctic Peninsula. Journal of Glaciology 46 (154): 516-530.

Scheidat, M., A. Friedlaender, K.H. Kock, L. Lehnert, O. Boebel, J. Roberts and R. Williams. 2011. Cetacean surveys in the Southern Ocean using icebreaker-supported helicopters. Polar Biology 34(10): 1513-1522.

Schloss, I.R., D. Abele, S. Moreau, S. Demers, A.V. Bers, O. Gonzalez and G.A. Ferreyra. 2012. Response of phytoplankton dynamics to 19-year (1991-2009) climate trends in Potter Cove (Antarctica). Journal of Marine Systems 92(1): 53-66.

Schneider, D.P., E.J. Steig, T.D. van Ommen, D.A. Dixon, P.A. Mayewski, J.M. Jones and C.M. Bitz. 2006. Antarctic temperatures over the past two centuries from ice cores. Geophysical Research Letters 33: DOI: 10.1029/2006GL027057.

Schneider, D.P., C. Deser and Y. Okumura. An assessment and interpretation of the observed warming of West Antarctica in the austral spring, 2012. Climate Dynamics 38(1-2): 323347.

Schwarz, J.N. and M.P. Schodlock . 2009. Impact of drifting icebergs on surface phytoplankton biomass in the Southern Ocean: ocean colour remote sensing and in situ iceberg tracking. Deep-Sea Research Part I-Oceanographic Research Papers 56: 1727-1741.

Screen, J.A. and I. Simmonds. 2012. Half-century air temperature change above Antarctica: observed trends and spatial reconstructions, Journal of Geophysical Research 117: D16108 DOI:10.1029/2012JD017885.

Sen Gupta, A., A. Santoso, A.S. Taschetto, C.C. Ummenhofer, J. Trevena and M.H. England. 2009. Projected changes to the Southern Hemisphere ocean and sea ice in the IPCC AR4 climate models. Journal of Climate 22 (11): 30473078.

Seppälä, A., C.E. Randall, M.A. Clilverd, E. Rozanov and C.J. Rodger, 2009. Geomagnetic activity and polar surface level air temperature variability. Journal of Geophysical Research 114, A10312: DOI:10.1029/2008JA014029.

Shakun, J.D. and A.E. Carlson. 2010. A global perspective on Last Glacial Maximum to Holocene climate change. Quaternary Science Reviews 29: 1801-1816.

Shepherd, A., E.R. Ivins, A. Geruo, V. R. Barletta, M.J. Bentley, S. Bettadpur, K. H. Briggs, D.H. Bromwich, R. Forsberg, N. Galin, M. Horwath, S. Jacobs, I. Joughin, M.A. King, J.T.M. 
Lenaerts, J. Li, S.R.M. Ligtenberg, A. Luckman, S.B. Luthcke, M. McMillan, R. Meister, G. Milne, J. Mouginot, A. Muir, J.P. Nicolas, J. Paden, A.J. Payne, H. Pritchard, E. Rignot, H. Rott, L.S. Sørensen, T. A. Scambos, B. Scheuchl, E.J.O. Schrama, B. Smith, A. V. Sundal, J.H. van Angelen, W.J. van de Berg, M. R. van den Broeke, D. G. Vaughan, I. Velicogna, J. Wahr, P.I. Whitehouse, D.J. Wingham, D. Yi, D. Young and H.J. Zwally. 2012. A reconciled estimate of ice-sheet mass balance. Science 338: 1183-1189.

Sigmond, M. and J.C. Fyfe. 2010. Has the ozone hole contributed to increased Antarctic sea ice extent? Geophysical Research Letters 37 DOI: 10.1029/2010GL044301.

Simmonds, I., K. Keay and E.P. Lim. 2003. Synoptic activity in the seas around Antarctica. Monthly Weather Review 131: 272-288.

Simmons, M.P. and W.J. Eliott. 2009. Climate change and cetaceans: concerns and recent developments. Journal of the Marine Biological Association of the United Kingdom 89: 203-210.

Siniff, D.B., R.A. Garrott, J.J. Rotella, W.R. Fraser and D.G. Ainley. 2008. Opinion projecting the effects of environmental change on Antarctic seals. Antarctic Science 20(5): 425435.

Smith, C.R., L.J. Grange, D.L. Honig, L. Naudts, B. Huber, L. Guidi and E. Domack. 2012. A large population of king crabs in Palmer Deep on the west Antarctic Peninsula shelf and potential invasive impacts. Proceedings of the Royal Society B-Biological Sciences 279(1730): 1017-1026.

Smith, W.O. and J.C. Comiso. 2008. Influence of sea ice on primary production in the Southern Ocean: A satellite perspective. Journal of Geophysical Research - Oceans 113(C5): DOI:10.1029/2007JC004251.

Sokolov, S. and S.R. Rintoul. 2009. Circumpolar structure and distribution of the Antarctic Circumpolar Current fronts: 2. Variability and relationship to sea surface height. Journal of Geophysical Research-Oceans 114: DOI: 10.1029/2008JC005248.

Somero, G.N. 2012. The physiology of global change: linking patterns to mechanisms. Annual Review of Marine Science 4: 39-61.

Stammerjohn, S., D.G. Martinson, R.C. Smith, X. Yuan and D. Rind. 2008. Trends in Antarctic annual sea ice retreat and advance and their relation to El Niño-Southern Oscillation and Southern Annular Mode variability. Journal of Geophysical Research 113: (doi:10.1029/2007JC004269).

Steig, E.J., Q. Ding, D.S. Battisti and A. Jenkins. 2012. Tropical forcing of Circumpolar Deep Water inflow and outlet glacier thinning in the Amundsen Sea Embayment, West Antarctica. Annals of Glaciology 53: (doi:10.3189/2012AoG60A110).

Steig, E.J., D.P. Schneider, S.D. Rutherford, M.E. Mann, J.C. Comiso and D.T. Shindell. 2009. Warming of the Antarctic ice-sheet surface since the 1957 International Geophysical Year. Nature 457: 459-462.

Sterken, M., S.J. Roberts, D.A. Hodgson, W. Vyverman, A. Balbo, K. Sabbe, S.G. Moreton and E. Verleyen. 2012. Holocene glacial and climate history of Prince Gustav Channel, northeastern Antarctic Peninsula. Quaternary Science Reviews 31: 93-111.

Stokstad, E. 2007. Boom and bust in a polar hot zone. Science 315(5818): 1522-1523.

Sumida, P.Y.G., A.F. Bernardino, V.P. Stedall, A.G. Glover and C.R. Smith. 2008. Temporal changes in benthic megafaunal abundance and composition across the West Antarctic Peninsula shelf: results from video surveys. Deep-Sea Research Part II-Topical Studies in Oceanography 55(22-23): 24652477.
Thoma, M., A. Jenkins, D. Holland and S. Jacobs. 2008. Modelling circumpolar deep water intrusions on the Amundsen Sea continental shelf, Antarctica. Geophysics Research Letters 35(18): 18-9-2008.

Thompson, D.W.J., S. Solomon, P.J. Kushner, M.H. England, K.M. Grise and D.J. Karoly. 2011. Signatures of the Antarctic ozone hole in Southern Hemisphere surface climate change. Nature Geoscience 4(11): 741-749.

Tomasi, C., A. Lupi, M. Mazzola, R.S. Stone, E.G. Dutton, A. Herber, V.F. Radionov, B.N. Holben, M.G. Sorokin, S.M. Sakerin, S.A. Terpugova, P.S. Sobolewski, C. Lanconelli, B.H. Petkov, M. Busetto and V. Vitale. 2012. An update on polar aerosol optical properties using POLAR-AOD and other measurements performed during the International Polar Year. Atmospheric Environment, 52: 29-47.

Treguier, A.M., J. Le Sommer, J.M. Molines and B. de Cuevas. 2010. Response of the Southern Ocean to the Southern Annular Mode: Interannual variability and multidecadal trend. Journal of Physical Oceanography 40(7): 1659-1668.

Trivelpiece, W.Z., J.T. Hinke, A.K. Miller, C.S. Reiss, S.G. Trivelpiece and G.M. Watters. 2011. Variability in krill biomass links harvesting and climate warming to penguin population changes in Antarctica. Proceedings of the National Academy of Sciences of the United States of America 108(18): 76257628.

Tschumi, T., F. Joos, M. Gehlen and C. Heinze. 2011. Deep ocean ventilation, carbon isotopes, marine sedimentation and the deglacial $\mathrm{CO}_{2}$ rise. Climate of the Past 7: 771800.

Turner, J., S.R. Colwell, G.J. Marshall, T.A. Lachlan-Cope, A.M. Carleton, P.D. Jones, V. Lagun, P.A. Reid and S. lagovkina. 2005. Antarctic climate change during the last 50 years. International Journal of Climatology 25: 279-294.

Turner, J., T.A. Lachlan-Cope, S.R. Colwell, G.J. Marshall and W.M. Connolley. 2006. Significant warming of the Antarctic winter troposphere. Science 311: 1914-1917.

Turner, J., R.A. Bindschadler, P. Convey, G. di Prisco, E. Fahrbach, J. Gutt, D.A. Hodgson, P.A. Mayewski and C.P. Summerhayes (editors). 2009a. Antarctic climate change and the environment. Cambridge: Scientific Committee on Antarctic Research.

Turner, J., J.C. Comiso, G.J. Marshall, T.A. Lachlan-Cope, T.J. Bracegirdle, T. Maksym, M. P. Meredith, Z. Wang and A. Orr. 2009b. Non-annular atmospheric circulation change induced by stratospheric ozone depletion and its role in the recent increase of Antarctic sea ice extent. Geophysical Research Letters 36: L08502 (DOI:10.1029/2009GL037524).

Turner, J. and G.J. Marshall. 2011. Climate change in the polar regions. Cambridge, Cambridge University Press.

Turner, J., T. Maksym, T. Phillips, G.J. Marshall and M.P. Meredith. 2012. Impact of changes in sea ice advance on the large winter warming on the western Antarctic Peninsula. International Journal of Climatology (DOI: 10.1002/joc.3474).

Turner, J., T.J. Bracegirdle, T. Phillips, G.J. Marshall and J.S. Hosking. 2013. An initial assessment of Antarctic sea ice extent in the CMIP5 models. Journal of Climate 26: 14731484.

Vaughan, D.G. and J.R. Spouge. 2002. Risk estimation of collapse of the West Antarctic ice sheet. Climatic Change 52: 65-91.

Vermeer, M. and S. Rahmstorf. 2009. Global sea level linked to global temperature. Proceedings of the National Academy of Science 106: 21527-21532.

Wang, Z., J. Chappellaz, K. Park, and J.E. Mak. 2010. Large variations in Southern Hemisphere biomass burning during the last 650 Years. Science 330(6011): 1663-1666. 
Watson, S. A., L.S. Peck, P.A. Tyler, P.C. Southgate, K.S. Tan, R.W. Day and S.A. Morley. 2012. Marine invertebrate skeleotn size varies with latitude, temperature and carbonate saturation: implications for global change and acidification. Global change Biology 18: 30263038.

Whitehouse, M.J., M.P. Meredith, P. Rothery, A. Atkinson, P. Ward, R.E. Korb. 2008. Long-term ocean warming at South Georgia, Southern Ocean: physical characteristics and implications for lower trophic levels. Deep-Sea Research 55(10): 1218-1228.
Woodworth, P.L., W.R. Gehrels and R.S. Nerem. 2011. Nineteenth and twentieth century changes in sea level. Oceanography 24(2): 80-93.

Zagorodnov, V., O. Nagornov, T.A. Scambos, A. Muto, E. Mosley-Thompson and S. Tyuflin. 2012. Borehole temperatures reveal details of 20th century warming at Bruce Plateau, Antarctic Peninsula. The Cryosphere 6: (DOI:10.5194/tc-6675-2012).

Zhang, J. 2007. Increasing Antarctic sea ice under warming atmospheric and oceanic conditions. Journal of Climate 20: 2515-2529. 